\title{
Crystal chemical significance of chemical zoning in dissakisite-(Ce)
}

Mihoko Hoshino ${ }^{1, *}$ Mitsuyoshi Kimata ${ }^{1}$ Norimasa Nishida ${ }^{2}$ Masahiro Shimizu ${ }^{1}$

${ }^{1}$ Earth Evolution Sciences, Graduate School of Life and Environmental Sciences, The University of Tsukuba, Ibaraki 305-8572, Japan

${ }^{2}$ Chemical Analysis Division, Research Facility Centre for Science and Technology, The University of Tsukuba, Ibaraki 305-8577, Japan

* E-mail address: hossy716@geol.tsukuba.ac.jp

Telephone number: +81-029-853-4544

Fax number: +81-029-853-7887

\begin{abstract}
Dissakisites from Trimouns dolomite mine, France, have two kinds of single crystals: chemical-zoned and homogeneous types. Back-scattered electron microprobe (BSE) images of these dissakisites reveal both $\mathrm{Ca}-\mathrm{Al}$ rich dark zones and Fe- $\mathrm{REE}$ rich bright zones. Crystal structures of three dark and two bright zones in a chemical-zoned dissakisite and of a homogeneous zone in unzoned dissakisite were refined to individual $\mathrm{R}$ indices (about 3.0-5.0\%) based on 1400 observed $\left[\left|\mathrm{F}_{0}\right|>4 \sigma \mathrm{F}_{0}\right]$ reflections measured with $\mathrm{MoK} \alpha \mathrm{X}$-radiation using single crystal diffractometer. The differences in brightness between their BSE images arise from those in coupled substitutions of the elements occupying A2 and M3 sites. The main reason for these differences is that ten-coordinated A2 polyhedra and M3 octahedra are directly linked through their shared edge, which creates a great potential for making this coupled substitution. This zoning indicates that formation of the whole zoned crystal, where each zone could be grown steadily with its crystallographic axes mutually parallel to each other, may be identified as autoepitaxy.
\end{abstract}

Keywords dissakisite $\cdot$ rare earth elements $\cdot$ chemical zoning $\cdot$ crystal structure $\cdot$ epitaxy 


\section{Introduction}

Dissakisite-(Ce) of an ideal formula $\mathrm{CaCeMgAl}_{2} \mathrm{Si}_{3} \mathrm{O}_{12}(\mathrm{OH})-\mathrm{a} \mathrm{Mg}$ analogue of allanite-(Ce) (e.g. Armbruster et al. 2006) — has been reported from some metamorphic occurrences (Grew et al. 1991; Enami and Zang 1988; Zakrzewski et al. 1992; De Parseval et al. 1997; Marty 2004). The crystal structure of dissakisite-(Ce) from the type locality (Grew et al. 1991) was first determined by Rouse and Peacor (1993), who found it to have the space group $P 2_{1} / m$, and demonstrated that $\mathrm{Ca}$ and lanthanide atoms were completely ordered in A1 and A2 sites, respectively. However, this structure refinement was not performed under compositional constraints; the chemical composition used for the final structural refinement is different from that determined by EMPA (Grew et al. 1991).

Though chemical zonings (the chemical zonations) have been generally known to reside in epidotes and allanites (e.g. Franz and Liebscher 2004; Catlos et al. 2000), the chemical zonings for dissakisite-(Ce), except for Cr-rich dissakisite-(Ce) (Yang and Enami 2003) and dissakisite-(La) (Tumiati et al. 2005), have been first observed by our present study of dissakisite-(Ce) from both Trimouns and the type locality, Balchen Mountain (Grew et al. 1991). Despite several occurrences of dissakisite, there are very few published studies on the compositional variation and crystal chemistry of this mineral.

The objectives of this paper are: (1) to describe chemical compositions of each zone in dissakisite-(Ce); (2) to refine the crystal structures of their zones and (3) to explain both the formation of their chemical zoning and its crystal chemistry.

\section{Experimental methods}

Sample description

The sample used in this study was dissakisite in dolomite lens from the talc-chlorite deposit of 
Trimouns in the French Pyrenees (De Parseval et al. 1997; Marty 2004). These dissakisites appear to be well-crystallised euhedral crystals, but have two kinds of colour: brown and transparent crystals (the former size: $0.5 \times 0.8 \times 3.0-1.0 \times 1.5 \times 5.0 \mathrm{~mm}$, the latter size: $0.3 \times 0.7 \times 2.5-1.0 \times 1.5 \times 3.0 \mathrm{~mm}$ ). These crystals were about several centimetres away from each other. For comparison, the crystals of light brown dissakisite- $(\mathrm{Ce})($ size: $0.05 \times 1.5-0.07 \times 2.5 \mathrm{~mm})$ in the marble lenses in quartzo-feldspathic gneisses from Balchen Mountain, East Antarctica, provided by Grew et al. (1989, 1991), were analysed, and are apparently equivalent to the type sample first described by Grew et al. (1991).

Chemical composition

Chemical analyses were performed using the JEOL JAX-8621 electron microprobe equipped with three wavelength-dispersion spectrometers (WDS) at the Chemical Analysis Division, University of Tsukuba. The present dissakisites were implanted in an epoxy resin and well polished. Chemical zonings of their minerals were measured with ultra-high precision back-scattered electron (BSE) images (Fig. 1a, b, c). Qualitative analyses for the zones were performed with $25 \mathrm{kV}$ accelerating potential and $250 \mathrm{nA}$ beam current. Moreover, qualitative analyses of $\mathrm{F}$ for the examined zones were performed with $15 \mathrm{kV}$ accelerating potential and $1000 \mathrm{nA}$ beam current. However, no fluorine was detected in these zones, although Grew et al. (1991) reported F contents (0.18-0.27 wt.\%) of dissakisites from Balchen Mountain. Elements detected with qualitative analyses were measured by quantitative analyses. Quantitative analyses for major elements ( $\mathrm{Si}, \mathrm{Ti}, \mathrm{Al}, \mathrm{Fe}, \mathrm{Mg}, \mathrm{Ca})$ of dissakisite were performed with an accelerating voltage of $25 \mathrm{kV}$, beam current of $10 \mathrm{nA}$, count times of $20 \mathrm{~s}$ and a beam diameter of $5 \mu \mathrm{m}$, while concentrations of REE were most effectively measured at $25 \mathrm{kV}$ with a beam current $50 \mathrm{nA}$, count times of $20 \mathrm{~s}$ and a beam diameter of $5 \mu \mathrm{m}$. Because of the very close spacing of the X-ray lines in the L spectra of the REEs, accurate electron microprobe analysis (EMPA) of REE-bearing minerals is experimentally 
challenging (Reed and Buckley 1998; Nishida et al. 1999, 2003).

The modified methods devised through careful measurement of these X-ray lines have improved the quality of the REE data collected by EMPA (Reed and Buckley 1998; Nishida et al. 1999, 2003): X-ray intensities of $\mathrm{La}, \mathrm{Ce}$ and $\mathrm{Nd}$ were measured at the $L \alpha_{1} \mathrm{X}$-ray line, while those of $\mathrm{Pr}, \mathrm{Sm}$ and Gd were measured at the $L \beta_{1}$ lines. Standards for REE were synthetic Ca-Al silicate glasses each containing REE, obtained from P \& H Development Ltd. The chemical compositions of the standards are given in Table 1 of Hoshino et al. (2005). All data were corrected with a ZAF matrix-correction program. The above-mentioned method for REE analysis has been applied successfully (Hoshino et al. 2005, 2006). Representative chemical compositions of the chemical zones are presented in Table 1. The occurrences of the present dissakisites from Trimouns and Balchen Mountain indicate that they are not associated with $\mathrm{Fe}^{3+}$-bearing minerals (Grew et al. 1989, 1991; De Parseval et al. 1997; Marty 2004). Furthermore, assignment of all $\mathrm{Fe}$ to both $\mathrm{Fe}^{2+}$ and $\mathrm{Fe}^{3+}$ led to no reasonable chemical formulae for the present dissakisites. Therefore, chemical formulae of dissakisite-(Ce) were calculated on $12 \mathrm{O}+1 \mathrm{OH}$ and all Fe were assumed to be $\mathrm{Fe}^{2+}$ (Grew et al. 1991; De Parseval et al. 1997).

Crystal structure analysis

Using the stereomicroscope, each zone of the examined crystals from Trimouns on the BSE images (Fig. 1a, b) was completely scooped out from the polished samples with a hard metal needle with constant reference to the BSE photographs, carefully selected for the structure refinements (Fig. 1a, b). The chemical-zoned dissakisite from Balchen Mountain was too small to perform the structure analysis for a single crystal (Fig. 1c). Single-crystal X-ray-diffraction intensities for dissakisites from Trimouns were obtained with an Enraf-Nonius CAD4 automated diffractometer with graphite-monochromated MoK $\alpha$ radiation. For each zoned crystal, twenty-five reflections in the range $20^{\circ} \leq 2 \theta \leq 30^{\circ}$ were centred, and 
the unit-cell dimensions (Table 2) were refined from the resultant setting angles using the least-squares technique. Intensity data were collected in the $\omega-2 \theta$ scan-mode at affixed scan-rate of $1.0^{\circ} 2 \theta / \mathrm{min}$. Psi-scan data were measured on 5 reflections at $10^{\circ}$ increments above the diffraction vector, and an absorption correction was applied using the semi-empirical method (North et al. 1968). The data were corrected for Lorentz, polarisation and background effects, averaged and reduced to structure factors; about 1400 unique reflections were observed $\left[\mathrm{F}_{0} \geq 4 \sigma\left(\mathrm{F}_{0}\right)\right]$.

\section{Results}

Chemical composition

Both chemical-zoned and homogeneous dissakisites are distinctly observed on BSE images (Fig. 1a, b, c). The former crystals display a series of chemically distinct zones that reflect overgrowth of different types of dissakisite. Moreover, the chemical zonings in the examined dissakisites are characterised by straight boundary limits. Our present observation confirms that there are several chemical zones with straight boundary limits in all the seven crystals of dissakisite-(Ce) from Balchen Mountain provided by Grew et al. (1991). As an example, one of these seven crystals is shown in Fig. 1c; the chemical compositions were determined (Table 1). The present chemical zonings (Fig. 1a, c) certainly represent the magmatic zoning evidenced by marking several different levels of composition with straight boundary limits (Poitrasson 2002; Gieré and Sorensen 2004). In the BSE image of dissakisites from Trimouns, dark brown crystals that can be seen with naked eye have chemical zoning while both light brown and transparent ones are homogeneous (Fig. 1a, b).

The quantitative EMPA of each zone demonstrated that Ce predominates La and all other REE in the analysed dissakisites; therefore, it can safely be said that the minerals from Trimouns (abbr, Tri 1-6) and Balchen Mountain (abbr, Bal 1-5) correspond to dissakisite-(Ce) (Table 1). These Tri- and Bal-dissakisites 
are LREE-enriched with $\mathrm{Ce}_{2} \mathrm{O}_{3}$ up to 11.18 and $10.8 \mathrm{wt} \%, \mathrm{La}_{2} \mathrm{O}_{3}$ up to 6.61 and $9.9 \mathrm{wt} \%$ and are abundant in other REE elements $\left(\mathrm{Nd}_{2} \mathrm{O}_{3}\right.$ up to 6.60 and $2.62 \mathrm{wt} \%, \mathrm{Pr}_{2} \mathrm{O}_{3}$ up 1.86 and $1.18 \mathrm{wt} \%, \mathrm{Sm}_{2} \mathrm{O}_{3}$ up 1.20 and $0.35 \mathrm{wt} \%, \mathrm{Gd}_{2} \mathrm{O}_{3}$ up 0.70 and $1.30 \mathrm{wt} \%$ ). The BSE images of the chemical-zoned crystals from Trimouns represent three dark zones (Tri 1-3) rich in $\mathrm{Ca}, \mathrm{Al}$ and $\mathrm{Mg}$ and two bright ones (Tri 4,5) rich in Fe and $\Sigma$ REE. Also, BSE images of zoned crystals from Balchen Mountain show three dark zones (Bal 1-3) rich in $\mathrm{Ca}$ and $\mathrm{Al}$ and two bright ones (Bal 4,5) rich in Fe and $\Sigma \mathrm{REE}$ (Table 1; Fig. 1a, b, c). It is widely known that most allanites preferentially incorporate minor radioactive elements of Th and $U$ and often occur in the metamict state (e.g. Deer et al. 1986). The present dissakisites from Trimouns and Balchen Mountain are not associated with radioactive minerals, and their $\mathrm{ThO}_{2}$ contents are below the detection limit. Therefore, they are suitable samples for crystal structure refinement.

Structure refinement

The SHELXL-97 (Sheldrick 1997) program was used throughout this work. The structure of dissakisite from Trimouns was refined in the space group $P 2_{l} / m$, with the structural parameters provided by Rouse and Peacor (1993). Although the unweighted and weighted R factors supplied by Rouse and Peacor (1993) are 2.4\% and 5.7\%, respectively, their structural data are almost consistent with those in this study (Tables 3, 4 and 5). In the final stage of refinement, a three-dimensional difference-Fourier map was calculated, but the hydrogen atom position was not determined.

Refinements were carried out with $\mathrm{Si}$ assigned to only tetrahedral sites, because it is routinely fixed on three tetrahedral sites of epidote group minerals (Peacor and Dunn 1988; Rouse and Peacor 1993). This normalization of the chemical data to $3 \mathrm{Si}$ per formula unit is consistent with rational establishment of the structural formulae calculated from the EPMA data (Table 1). Form factors for Ca and ( $\mathrm{REE}+$ Ca) were applied, where $\Sigma$ REE correspond to $\mathrm{La}, \mathrm{Ce}, \mathrm{Pr}, \mathrm{Nd}, \mathrm{Sm}$ and $\mathrm{Gd}$. Occupancies of $\mathrm{Ca}$ in A1 site 
and $(\Sigma \mathrm{REE}+\mathrm{Ca})$ in $\mathrm{A} 2$ site were refined together with coordinates and isotropic temperature factors to determine the distribution of $\mathrm{Ca}$ and $(\Sigma \mathrm{REE}+\mathrm{Ca})$ contents in $\mathrm{A} 1$ and $\mathrm{A} 2$ sites of dissakisite. Form factors for M1, M2 and M3 were modelled with $\mathrm{Al}^{3+}, \mathrm{Al}^{3+}$ and $\left(\mathrm{Al}^{3+}+\mathrm{Fe}^{2+}+\mathrm{Mg}^{2+}\right)$ respectively, based on the considerations of charge balance, similar refinements for other epidote group minerals (e.g. Dollase 1971; Kvick et al. 1988; Rouse and Peacor 1993), and known interatomic distances in dissakisite (Rouse and Peacor 1993). In particular, $\mathrm{A} 1^{3+}$ has a strong preference for $\mathrm{M} 2$ in epidote structures, whereas, clarifying any ambiguity in the distribution of other cations through refinement is difficult because of the similarity in respective form factors of $\mathrm{Al}^{3+}$ and $\mathrm{Mg}^{2+}$. Therefore, the occupancies of $\mathrm{M} 1$ and $\mathrm{M} 3$ sites were assigned on the basis of the representative EMPA values (Tables 1 and 6). The refined structural data for the six zones of Tri1 to Tri6 did not differ greatly from one another. Therefore, the structural data for Tri 1 (minimum brightness), Tri 5 (maximum brightness) and Tri 6 (homogenous) are representatively given as follows: final atomic coordinates and anisotropic displacement parameters are presented in Table 3; selected interatomic distances are provided in Table 4 and bond valences analysis is given in Table 5 . Assigned and refined site occupancies of dissakisites from Trimouns are shown in Table 6. The present chemical-zoned dissakisites from Balchen Mountain (Bal 1-5) were too small to perform structure analysis for a single crystal. Therefore, the site occupancies for dissakisite from Balchen Mountain (Bal 1-5) were correspondingly assigned on the basis of the representative EPMA values (Tables 1 and 6).

Data for atomic coordinates, anisotropic displacement parameters, selected interatomic distances and bond valence analysis of Tri 2, Tri 3 and Tri 4 can be obtained from the first author (M. Hoshino).

\section{Discussion}

Crystal chemistry of dissakisite-(Ce)

Chemical zoning of the present dissakisites (Fig. 1a, c), marking several different levels of 
composition with straight limits, certainly represents magmatic zoning (Poitrasson 2002; Gieré and Sorensen 2004). All of seven examined dissakisite crystals (see Fig. 1c for one of the seven crystals) from Balchen Mountain have tiny chemical zones with straight boundary limits, which were not described by Grew et al. (1991). Thus, it is difficult to collect a single crystal of dissakisite-(Ce) from Balchen Mountain available for crystal structure analysis (Rouse and Peacor 1993) because the crystals show complex chemical zoning in the order of $10 \mu \mathrm{m}$ (Fig. 1c). Furthermore, the chemical composition dictated by the structural refinement of dissakisite from Balchen Mountain (Rouse and Peacor 1993) differs considerably from that analysed by EMPA (Grew et al. 1991). It is significant that the crystal structure of the present dissakisite from Trimouns was refined under the constraints of accurate chemical composition by EMPA (Tables 1 and 6). The crystal structure of dissakisite-(La) has been determined by Lavina et al. (2006). Its lattice constants $\left(\mathrm{a}=8.959 \AA, \mathrm{b}=5.7226 \AA, \mathrm{c}=10.232 \AA, \beta=115.19^{\circ}\right.$ for untreated DISS3) are larger than those of dissakisite-(Ce): $\mathrm{a}=8.890-8.900 \AA, \mathrm{b}=5.6716-5.6938 \AA, \mathrm{c}=10.090-10.097 \AA$, $\beta=114.705-114.838^{\circ}$ for Tri 1 -Tri 6 in this study and $\mathrm{a}=8.905 \AA, \mathrm{b}=5.684 \AA, \mathrm{c}=10.113 \AA, \beta=$ $114.62^{\circ}$ in Rouse and Peacor (1993). The expansion of lattice constants for dissakisite-(La) is interpreted to be caused by metamictisation (Lavina et al. 2006); atomic displacement parameters of A1, A2, O8 and O9 are very large for metamict dissakisite-(La). Although atomic displacement parameters for A1 and A2 sites of metamict dissakisite-(La) are nearly equal to those of the present dissakisite-(Ce) from Trimouns, atomic displacement parameters for $\mathrm{O} 8$ and $\mathrm{O} 9$ for the former dissakisite are significantly larger than those for the latter. Thus, this difference suggests that the present dissakisite-(Ce) from Trimouns is non-metamict.

The bond valence sum was calculated to establish the credibility of the refined crystal structure. The calculation was done from the process parameters provided by Brese and O'Keeffe (1991). Bond valences of $\mathrm{O} 4$ and $\mathrm{O} 10$ are undersaturated in comparison with the ideal bond valence, 2.00, for $\mathrm{O}$ atom (Table 5). The bond valence sums for $\mathrm{O} 4$ and $\mathrm{O} 10$ are $1.63-1.68$ and $1.28-1.32$ v.u., respectively, implying that the 
$\mathrm{O} 10$ atom is the donor oxygen for the $\mathrm{H}$ atom (Table 5). Although $\mathrm{H}$ atom position was not determined on the Difference-Fourier map, inspection of the bond valence sums reveals that the $H$ atom is uniquely located at the $\mathrm{O} 10$ atom and involved in a hydrogen bond with $\mathrm{O} 4$. From the viewpoint of bond valence sums (Brown 1976; Hawthorne 1992), the chemical bonds between $\mathrm{O} 10$ and $\mathrm{H}$ in the present dissakisites are consistent with those in ferriallanite-(Ce) (Kartashov et al. 2002) and allanite-(Ce) (Hoshino et al. 2005).

Mechanism of chemical zoning in dissakisite-(Ce)

The charge-coupled substitution of $\mathrm{REE}^{3+}$ and $\mathrm{Mg}^{2+}$ for $\mathrm{Ca}^{2+}$ and $\mathrm{Al}^{3+}$ respectively relates dissakisite to clinozoisite (Gieré and Sorensen 2004) (Fig. 2a), and one of the most noticeable differences between these two minerals is that the ideal dissakisite contains only $\mathrm{Mg}^{2+}$ in the $\mathrm{M} 3$ site, whereas the endmember clinozoisite contains $\mathrm{Al}^{3+}$ (Ercit 2002). The differences in brightness between BSE images of dissakisites from Trimouns and Balchen Mountain cannot be explained by simple coupled substitutions, but by the following ones (Fig. 2a): in Trimouns dissakisite $\mathrm{Ca}^{2+}(\mathrm{A} 2)+\left(\mathrm{Mg}^{2+}+\mathrm{Al}^{3+}\right)(\mathrm{M} 3) \leftrightarrow \Sigma \mathrm{REE}^{3+}(\mathrm{A} 2)+2 \mathrm{Fe}^{2+}$ (M3), where the former is darker than the latter; however, in Balchen Mountain dissakisite $\mathrm{Ca}^{2+}(\mathrm{A} 2)+$ $\mathrm{Al}^{3+}(\mathrm{M} 1) \leftrightarrow \Sigma \mathrm{REE}^{3+}(\mathrm{A} 2)+\mathrm{Fe}^{2+}(\mathrm{M} 1)$, the former is darker than the latter (Table 6; Fig. 2b, c). A crucial difference in the occupancy site of those elements participating in the above coupled substitutions has arisen between $\mathrm{A} 2$ and $\mathrm{M} 3$ sites in Trimouns dissakisite and between $\mathrm{A} 2$ and $\mathrm{M} 1$ ones in Balchen Mountain (Table 6). Moreover, close observation of these zones under polarising microscope reveals that they have simultaneous extinction with one another (Fig. 1a, c). Both chemical zoning of the present dissakisite-(Ce) and the simultaneous extinction of these zones with one another demonstrate that formation of the whole zoned crystal, grown jointly with mutually parallel axes in the open system, may be identified as autoepitaxy (Bonev 1972). 
The variation in each crystal structure of zoned dissakisite-(Ce) from Trimouns may be checked by comparing the volumes of two A, three M and three Si polyhedra, calculated using the IVTON computer program (Balić-Žunić and Vickovic 1996) (Table 7). As a result, the volumes of A1, (M1, M2) and (Si1-Si3) sites ordered by $\mathrm{Ca}, \mathrm{Al}$ and $\mathrm{Si}$ cations, respectively, were similar among six refined crystals. On the other hand, the sum of volumes of $\mathrm{A} 2$ and $\mathrm{M} 3$ sites occupied by ( $\mathrm{REE}$ and $\mathrm{Ca})$ and $(\mathrm{Mg}, \mathrm{Al}$ and $\mathrm{Fe})$ atoms, respectively, bears a linear relationship to the length of the $\mathrm{b}$ axis, albeit unchangeable against the a and c axes (Fig. 3). Lattice parameters of dissakisite-(La) in the Ulten zone are plotted far away from those of the present dissakisite-(Ce) in Trimouns (Fig. 3), probably because of the expansion of lattice parameters caused by strong metamictisation (Lavina et al. 2006). Moreover, lattice parameters of dissakisite-(Ce) from Balchen Mountain determined by Rouse and Peacor (1993) are also plotted apart from those of the present dissakisite-(Ce) (Fig. 3) because the values of A2 and M3 site-occupancies refined to the former dissakisite-(Ce) (Rouse and Peacor 1993) differ from the EMPA ones obtained by the present study (Tables 1 and 6). Although Bonazzi and Menchetti (1995) showed that the presence of $\mathrm{REE}^{3+}$ decreases the unit-cell parameters, $\mathrm{c}$ and $\beta$, of epidote group minerals and increases both $b$ values of their unit cells and volumes (see Fig. 2 in Gieré and Sorensen (2004)), these relationships have not been observed in the present dissakisites. Higher $\Sigma$ REE and $\mathrm{Fe}^{2+}$ contents at A2 and M3 sites in a bright zone of the present dissakisite-(Ce) from Trimouns promote expansion of the corresponding polyhedra because of the coupled substitution of $\mathrm{Ca}^{2+}(\mathrm{A} 2)+\left(\mathrm{Mg}^{2+}+\mathrm{Al}^{3+}\right)(\mathrm{M} 3) \leftrightarrow \Sigma \mathrm{REE}^{3+}(\mathrm{A} 2)+2 \mathrm{Fe}^{2+}$ (M3): sum of A2 and M3 polyhedral volumes in the bright zone, enriched in $\Sigma \mathrm{REE}$ and $\mathrm{Fe}^{2+}$, are larger than those in the dark zone (Table 7). Furthermore, the volume expansion of A2 and M3 polyhedra exerts a potent influence on the $\mathrm{b}$ axis of dissakisite-(Ce) (Fig. 3): ten-coordinated A2 polyhedra share an edge with M3 octahedra (Fig. 4), and so the cations occupying the other polyhedra adjacent to these two polyhedra can easily mediate the charge difference in the above coupled substitution between A2 and M3 polyhedral cations. Therefore, this type of chemical zoning may be promoted by the wide diversity of chemical 
composition, even in a single crystal in thermodynamic equilibrium. Great tolerance of the dissakisite-(Ce) structure for this diversity can bring on autoepitaxy in the present chemical zoning.

\section{Acknowledgments}

The authors would like to thank Prof. E. S. Grew (University of Maine) for providing both reference samples from Balchen Mountain, East Antarctica, and some suggestions about this study. The authors are indebted to Dr. A. Kyono (University of Tsukuba) for access to the analytical facilities. This work was funded by a grant from Research Fellowships of the Japan Society for the Promotion of Science for Young Scientists.

\section{References}

Ambruster T, Bonazzi P, Akasaka M, Bermanec V, Chopin C, Gieré R, Heuss-Assbichler S, Liebscher A, Menchetti S, Pan Y, Pasero M (2002) Recommended nomenclature of epidote-group minerals. Eur J Mineral 18: 551-567

Balić-Žunić T, Vickovic I (1996) IVTON - program for the calculation of geometrical aspects of crystal structures and some crystal chemical applications. J Appl Cryst 29: 305-306

Bonazzi P, Menchetti S (1995) Monoclinic members of the epidote group: effects of the $\mathrm{Al} \leftrightarrow \mathrm{Fe}^{3+} \leftrightarrow$ $\mathrm{Fe}^{2+}$ substitution and of the entry of $\mathrm{REE}^{3+}$. Mineral Petrol 53: 133-153

Bonev I (1972) On the terminology of the phenomena of mutual crystal orientation. Acta Cryst A28: 508-512

Brese NE, O’Keeffe M (1991) Bond-valence parameters for solids. Acta Cryst B47: 192-197

Brown ID (1976) On the geometry of O-H...O hydrogen bonds. Acta Cryst B32: 24-31.

Catlos EJ, Sorensen SS, Harrison TM (2000) Th-Pb ion-microprobe dating of allanite. Am Mineral 85: 633-648 
De Parseval P, Fontan F, Aigouy T (1997) Chemical composition of REE minerals from Trimouns (French Pyrenees). Comptes Rendus de l'Académie des Sciences, Série II : Sciences de la Terre et des Planétes 324 : 625-630

Deer WA, Howie RA, Zussman J (1986) Allanite. In: Rock-forming Minerals, 2nd ed., Vol. 1B. Longman Scientific and Technical, Essex, England, pp. 151-179

Dollase WA (1971) Refinement of the crystal structures of epidote, allanite and hancockite. Am Mineral 56: 447-464

Enami M, Zang Q (1988) Magnesian staurolite in garnet-corundum rocks and eclogite from the Donghai district, Jiangsu province, east China. Am Mineral 73: 48-56

Ercit TS (2002) The mess that is "allanite”. Can Mineral 40: 1411-1419.

Franz G, Liebscher A (2004) Physical and chemical properties of the epidote minerals - an introduction-. In: Liebscher A, Franz G (eds) Epidote. Reviews in Mineralogy and Geochemistry 56: 1-82. Mineralogical Society of America and the Geochemical Society, Washington DC

Gieré R, Sorensen SS (2004) Allanite and other REE-rich epidote-group minerals. In: Liebscher A, Franz, G (eds) Epidote. Reviews in Mineralogy and Geochemistry 56: 431-493. Mineralogical Society of America and the Geochemical Society, Washington DC

Grew ES, Asami M, Makimoto H (1989) Preliminary petrological studies of the metamorphic rocks of the eastern Sør Rondane Mountains. Proceedings of the NIPR Symposium on Antarctic Geosciences 3: 100-127

Grew ES, Essene EJ, Peacor DR, SU, S-C, Asami M (1991) Dissakisite-(Ce), a new member of the epidote group and the Mg analogue of allanite-(Ce), from Antarctica. Am Mineral 76: 1990-1997 Hawthorne FC (1992) Bond topology, bond valence and structure stability. In: Price GD, Ross NL (eds) The stability of Minerals. The Mineralogical Society Series, 3. Chapman\& Hall, London, pp.25-87 Hoshino M, Kimata M, Nishida N, Kyono A, Shimizu M, Takizawa S (2005) The chemistry of allanite 
from the Daibosatsu Pass, Yamanashi, Japan. Mineral Mag 69: 403-423

Hoshino M, Kimata M, Shimizu M, Nishida N, Fujiwara T (2006) Allanite-(Ce) in granitic rocks from Japan: genetic implications of patterns of REE and Mn enrichment. Can Mineral 44: 45-62

Kartashov PM, Ferraris G, Ivaldi G, Sokolova E, McCammon C (2002) Ferriallanite-(Ce),

$\mathrm{CaCeFe}^{3+} \mathrm{AlFe}^{2+}\left(\mathrm{SiO}_{4}\right)\left(\mathrm{Si}_{2} \mathrm{O}_{7}\right) \mathrm{O}(\mathrm{OH})$, a new member of the epidote group: description, X-ray and Mössbauer study. Can Mineral 40: 1641-1648

Kvick A, Pluth JJ, Richardson Jr. JW, Smith JV (1988) The ferric ion distribution and hydrogen bonding in epidote: a neutron diffraction study at 15K. Acta Cryst B44: 351-355

Lavina B, Carbonin S, Russo U, Tumiati S (2006) The crystal structure of dissakisite-(La) and structural variations after annealing of radiation damage. Am Mineral 91: 104-110

Marty F (2004) The Trimouns Quarry Luzenac, Ariège, France. Mineral Record 35: 225-247

Nishida N, Kimata M, Sugimoto A (1999) Quantitative electron-probe microanalysis of various kinds of rare-earth elements in minerals. J Mineral SocJapan 28: 71-81 (in Japanese with English abstract)

Nishida N, Kimata M, Sugimoto A, Kyono A, Hatta T (2003) Quantitative analysis of minerals containing various kinds of rare earth elements in large quantities: Chemical composition of thortveitite.

Recent Res Devel Mineral 3: 1-16

North ACT, Phillips DC, Mathews FS (1968) A semi-empirical method of absorption correction. Acta Cryst A24: 351-359

Peacor DR, Dunn PJ (1988) Dollaseite-(Ce) (magnesium orthite redefined): structure refinement and implications for $\mathrm{F}+\mathrm{M}^{2+}$ substitutions in epidote-group minerals. Am Mineral 73: 838-842

Poitrasson F (2002) In situ investigations of allanite hydrothermal alteration: examples from calc-alkaline and anorogenic granites of Corsica (southeast France). Contib Mineral Petrol 142: 485-500

Reed SJB Buckley A (1998) Rare-earth element determination in minerals by electron-probe 
micro-analysis: application of spectrum synthesis. Mineral Mag 62: 1-8

Rouse RC, Peacor DR (1993) The crystal structure of dissakisite-(Ce), the Mg analogue of allanite-(Ce).

Can Mineral 31: 153-157

Sheldrick GM (1997) SHELXL-97. A program for the refinement of crystal structures. University of Göttingen, Germany

Tumiati S, Godard G, Martin S, Nimis P, Mair V, Boyer B (2005) Dissakisite-(La) from the Ulten zone peridotite (Italian Eastern Alps): a new end-member of the epidote group. Am Mineral 90: $1177-1185$

Yang J-J, Enami M (2003) Chromian dissakisite-(Ce) in a garnet lherzolite from the Chinese Su-Lu UHP metamorphic terrane: implication for $\mathrm{Cr}$ incorporation in epidote-group minerals and recycling of REE into the Earth's mantle. Am Mineral 88: 604-610

Zakrzewski MA, Lustenhouwer WJ, Nugteren HJ, Williams CT (1992) Rare-earth minerals yttrian zirconolite and allanite-(Ce)* and associated minerals from Koberg mine, Bergslagen, Sweden. Mineral Mag 56: 27-35 
Table 1. Electron microprobe analyses of dissakisites from Trimouns (Tri 1-5: chemical zoned, Tri 6: homogeneous) and Balchen Mountain (Bal 1-5: chemical zoned)

\begin{tabular}{|c|c|c|c|c|c|c|c|c|c|c|c|}
\hline $\operatorname{spot}^{a}$ & $\begin{array}{l}\text { Tri } 1 \\
\text { Dark } \\
\text { zone } \\
4\end{array}$ & $\begin{array}{l}\text { Tri } 2 \\
\text { Dark } \\
\text { zone } \\
7\end{array}$ & $\begin{array}{c}\text { Tri } 3 \\
\text { Dark } \\
\text { zone } \\
4\end{array}$ & $\begin{array}{c}\text { Tri } 4 \\
\text { Bright } \\
\text { zone } \\
7\end{array}$ & $\begin{array}{c}\text { Tri } 5 \\
\text { Bright } \\
\text { zone } \\
7\end{array}$ & $\begin{array}{c}\text { Tri } 6 \\
\text { Homogeneous } \\
\text { zone } \\
7\end{array}$ & $\begin{array}{c}\text { Bal } 1 \\
\text { Dark } \\
\text { zone } \\
6\end{array}$ & $\begin{array}{c}\text { Bal } 2 \\
\text { Dark } \\
\text { zone } \\
6\end{array}$ & $\begin{array}{c}\text { Bal } 3 \\
\text { Dark } \\
\text { zone } \\
4\end{array}$ & $\begin{array}{c}\text { Bal } 4 \\
\text { Bright } \\
\text { zone } \\
6\end{array}$ & $\begin{array}{c}\text { Bal } 5 \\
\text { Bright } \\
\text { zone } \\
4\end{array}$ \\
\hline $\mathrm{SiO}_{2}$ & $33.00(6)$ & $33.29(5)$ & $33.55(4)$ & $32.99(6)$ & $32.85(6)$ & $33.15(7)$ & $34.1(1)$ & $34.16(3)$ & $34.0(4)$ & $33.9(2)$ & $33.8(2)$ \\
\hline $\mathrm{TiO}_{2}$ & n.d..$^{\mathrm{c}}$ & n.d. & n.d. & n.d. & n.d. & n.d. & $1.2(1)$ & $1.17(1)$ & $1.19(9)$ & $1.22(8)$ & $1.25(1)$ \\
\hline $\mathrm{Al}_{2} \mathrm{O}_{3}$ & $19.81(6)$ & $19.57(6)$ & $19.87(6)$ & $19.74(3)$ & $19.26(3)$ & $19.49(2)$ & $17.5(1)$ & $17.3(1)$ & $17.35(8)$ & $16.1(2)$ & $15.89(3)$ \\
\hline $\mathrm{Fe}_{2} \mathrm{O}_{3}$ & - & - & - & - & - & - & - & - & - & - & - \\
\hline $\mathrm{La}_{2} \mathrm{O}_{3}$ & $6.02(5)$ & $6.44(5)$ & $6.61(4)$ & $5.84(2)$ & $6.45(7)$ & $6.52(6)$ & $9.8(1)$ & $9.77(1)$ & $9.9(2)$ & $9.4(1)$ & $9.6(1)$ \\
\hline $\mathrm{Ce}_{2} \mathrm{O}_{3}$ & $10.47(4)$ & $10.88(4)$ & $10.87(4)$ & $10.80(7)$ & $11.18(7)$ & $10.89(7)$ & $9.94(7)$ & $9.8(2)$ & $10.1(1)$ & $10.8(2)$ & $10.73(2)$ \\
\hline $\mathrm{Pr}_{2} \mathrm{O}_{3}$ & $1.77(3)$ & $1.79(3)$ & $1.69(3)$ & $1.72(6)$ & $1.59(4)$ & $1.86(4)$ & $0.99(5)$ & $1.02(1)$ & $1.03(5)$ & $1.18(2)$ & $1.11(1)$ \\
\hline $\mathrm{Nd}_{2} \mathrm{O}_{3}$ & $07(3)$ & $6.02(2)$ & $5.81(2)$ & $6.60(3)$ & $5.38(5)$ & $5.64(4)$ & $2.13(1)$ & $2.17(1)$ & $2.14(3)$ & $2.62(8)$ & $2.54(1)$ \\
\hline $\mathrm{Sm}_{2} \mathrm{O}_{3}$ & $12(2)$ & $1.06(4)$ & $1.04(3)$ & $1.20(2)$ & $0.84(2)$ & $0.86(3)$ & $0.33(2)$ & $0.34(2)$ & $0.31(3)$ & $0.35(3)$ & $0.35(4)$ \\
\hline $\mathrm{Gd}_{2} \mathrm{O}_{3}$ & $59(2)$ & $0.60(2)$ & $0.51(5)$ & $0.70(5)$ & $0.44(5)$ & $0.54(4)$ & $1.17(3)$ & $1.19(3)$ & $1.15(1)$ & $1.30(3)$ & $1.26(1)$ \\
\hline $\mathrm{FeO}^{\mathrm{d}}$ & $3.12(8)$ & $3.41(7)$ & $3.65(6)$ & $3.35(6)$ & $4.32(5)$ & $4.50(4)$ & $2.47(7)$ & $2.49(6)$ & $2.55(3)$ & $3.13(4)$ & $3.12(2)$ \\
\hline & $37(2)$ & $4.82(3)$ & $4.85(3)$ & 4.40 & & $4.27(2)$ & $7.17(6)$ & $7.22(1)$ & $7.10(1)$ & $7.7(3)$ & $7.8(4)$ \\
\hline $\mathrm{CaO}$ & $11.41(2)$ & $11.41(3)$ & $11.45(4)$ & $11.38(5)$ & $10.97(4)$ & $10.75(4)$ & $11.36(3)$ & $11.39(1)$ & $11.4(2)$ & $10.4(1)$ & $10.6(3)$ \\
\hline $\mathrm{H}_{2} \mathrm{O}(\text { calc })^{\mathrm{e}}$ & 1.64 & 1.66 & 1.67 & 1.64 & 1.61 & 1.64 & 1.68 & 1.67 & 1.67 & 1.65 & 1.66 \\
\hline Total & 99.89 & 100.95 & 101.57 & 100.36 & 98.70 & 100.11 & 99.84 & 99.69 & 99.89 & 99.75 & 99.71 \\
\hline & \multicolumn{11}{|c|}{ Normalized on the basis of $12 \mathrm{O}+(\mathrm{OH})$} \\
\hline $\mathrm{Si}$ & $3.005(8)$ & $3.015(7)$ & $3.012(7)$ & $3.009(7)$ & $3.044(7)$ & $3.030(8)$ & $3.06(3)$ & $3.07(4)$ & $3.06(6)$ & $3.08(3)$ & $3.08(3)$ \\
\hline $\mathrm{Ti}$ & n.d. & n.d. & n.d. & n.d. & n.d. & n.d. & $0.08(1)$ & $0.079(1)$ & $0.08(1)$ & $0.08(1)$ & $0.09(3)$ \\
\hline $\mathrm{Al}$ & $2.126(8)$ & $2.089(9)$ & $2.102(9)$ & $2.122(8)$ & 2.103(7) & $2.100(5)$ & $1.85(2)$ & $1.83(1)$ & $1.84(2)$ & $1.73(3)$ & $1.71(1)$ \\
\hline $\mathrm{Fe}^{3+}$ & - & - & - & - & - & - & - & - & - & - & - \\
\hline $\mathrm{La}$ & $0.202(3)$ & $0.215(3)$ & $0.219(3)$ & $0.196(2)$ & $0.220(4)$ & $0.220(4)$ & $0.325(7)$ & $0.324(1)$ & $0.33(2)$ & $0.32(1)$ & $0.323(3)$ \\
\hline $\mathrm{Ce}$ & $0.349(3)$ & $0.361(3)$ & $0.357(3)$ & $0.361(5)$ & $0.379(5)$ & $0.364(5)$ & $0.327(5)$ & $0.32(1)$ & $0.33(9)$ & $0.36(1)$ & $0.358(6)$ \\
\hline $\operatorname{Pr}$ & $0.059(2)$ & $0.059(2)$ & $0.055(2)$ & $0.057(4)$ & $0.054(3)$ & $0.062(3)$ & $0.032(3)$ & $0.033(1)$ & $0.034(3)$ & $0.039(1)$ & $0.037(0)$ \\
\hline $\mathrm{Nd}$ & $0.197(2)$ & $195(2)$ & $0.186(1)$ & $0.215(2)$ & $0.178(3)$ & $0.184(3)$ & $068(1)$ & $0.070(1)$ & $0.069(1)$ & $0.085(6)$ & $0.083(0)$ \\
\hline Sm & $0.035(2)$ & $0.033(2)$ & $0.032(2)$ & $0.038(1)$ & $0.027(2)$ & $0.027(2)$ & $0.010(1)$ & $0.011(1)$ & $0.010(2)$ & $0.011(2)$ & $0.011(2)$ \\
\hline Gd & $0.018(1)$ & $0.018(1)$ & $0.015(3)$ & $0.021(3)$ & $0.014(3)$ & $0.016(2)$ & $0.035(1)$ & $0.035(1)$ & $0.034(1)$ & $0.039(2)$ & $0.038(0)$ \\
\hline $\mathrm{Fe}^{2+}$ & $0.238(8)$ & $0.258(8)$ & $0.274(8)$ & $0.256(8)$ & $0.335(7)$ & $0.344(7)$ & $0.19(1)$ & $0.187(8)$ & $0.192(7)$ & $0.238(5)$ & $0.238(7)$ \\
\hline $\mathrm{Mg}$ & $0.661(7)$ & $0.651(8)$ & $0.649(8)$ & $0.598(7)$ & $0.526(7)$ & $0.582(5)$ & $0.96(1)$ & $0.968(8)$ & $0.95(1)$ & $1.04(5)$ & $1.06(6)$ \\
\hline $\mathrm{Ca}$ & $1.113(8)$ & $1.107(7)$ & $1.101(6)$ & $1.112(9)$ & $1.089(6)$ & $1.053(7)$ & $1.093(5)$ & $1.098(5)$ & $1.10(4)$ & $1.02(2)$ & $1.03(4)$ \\
\hline Sum REE & 0.860 & & 0.864 & 0.888 & 0.872 & 0.873 & 0.797 & 0.793 & 0.807 & 0.854 & 0.850 \\
\hline Sum Cat & 8.002 & 8.000 & 8.004 & 7.986 & 7.969 & 7.983 & 8.03 & 8.03 & 8.03 & 8.04 & 8.05 \\
\hline $\mathrm{OH}$ (stoich) & 1.000 & 1.000 & 1.000 & 1.000 & 1.000 & 1.000 & 1.00 & 1.00 & 1.00 & 1.00 & 1.00 \\
\hline
\end{tabular}

${ }^{\text {a }}$ See Fig. 1a, b, c for spot locations

${ }^{\mathrm{b}}$ Number of microprobe points; number in parenthesis is standard deviation

${ }^{c}$ n.d.: not detected

${ }^{\mathrm{d}} \mathrm{All} \mathrm{Fe}$ as assumed to $\mathrm{Fe}^{2+}$

${ }^{\mathrm{e}}$ Calculated assuming $12 \mathrm{O}+(\mathrm{OH})$ 
Table 2 Details on data collection and refinement of dissakisite from Trimouns

\begin{tabular}{|c|c|c|c|c|c|c|}
\hline & \multicolumn{5}{|c|}{ Enraf-Nonius CAD4 } \\
\hline \multicolumn{2}{|l|}{ Wavelength } & \multicolumn{5}{|c|}{ MoK $\alpha$ radiation $(\lambda=0.71069 \AA)$} \\
\hline \multicolumn{2}{|l|}{ Temperature } & \multicolumn{5}{|c|}{$296 \mathrm{~K}$} \\
\hline \multicolumn{2}{|c|}{ Scan mode } & \multicolumn{5}{|l|}{$\omega / 2 \theta$} \\
\hline \multicolumn{2}{|c|}{ Criterion for type unobserved reflections } & \multicolumn{5}{|l|}{$\mathrm{F}_{0}>4 \sigma\left(\mathrm{F}_{0}\right)$} \\
\hline \multicolumn{2}{|c|}{ Number of refined parameters: } & \multicolumn{5}{|l|}{119} \\
\hline \multicolumn{2}{|c|}{ structure refinement program used } & \multicolumn{5}{|l|}{ SHELXL-97 } \\
\hline crystal & Tri 1 & Tri 2 & Tri 3 & $\operatorname{Tri} 4^{\mathrm{a}}$ & Tri 5 & Tri 6 \\
\hline$a(\AA)$ & $8.899(2)$ & $8.891(2)$ & $8.898(3)$ & $8.893(3)$ & $8.895(2)$ & $8.900(2)$ \\
\hline$b(\AA)$ & $5.6836(6)$ & $5.6716(5)$ & $5.684(1)$ & $5.689(3)$ & $5.6910(6)$ & $5.6938(6)$ \\
\hline$c(\AA)$ & $10.095(2)$ & $10.091(2)$ & $10.094(3)$ & $10.090(3)$ & $10.097(2)$ & $10.096(2)$ \\
\hline$\beta\left(^{\circ}\right)$ & $114.729(9)$ & $114.838(8)$ & 114.713(9) & $114.83(1)$ & $114.710(9)$ & $114.705(9)$ \\
\hline$V\left(\AA^{3}\right)$ & $463.7(2)$ & $461.8(1)$ & $463.8(2)$ & $463.2(2)$ & $464.3(2)$ & $464.8(2)$ \\
\hline Space group & $P 2{ }_{1} / m$ & $P 2{ }_{1} / m$ & $P 2{ }_{1} / m$ & $P 2{ }_{1} / m$ & $P 2{ }_{1} / m$ & $P 2_{1} / m$ \\
\hline$Z$ & 2 & 2 & 2 & 2 & 2 & 2 \\
\hline Crystal size(mm) & $0.1 \times 0.2 \times 0.2$ & $0.2 \times 0.2 \times 0.2$ & $0.2 \times 0.2 \times 0.2$ & $0.1 \times 0.1 \times 0.05$ & $0.3 \times 0.3 \times 0.2$ & $0.2 \times 0.3 \times 0.2$ \\
\hline $2 \theta_{\max }$ & 60 & 60 & 60 & 60 & 60 & 60 \\
\hline Total reflections & 1544 & 1538 & 1548 & 1541 & 1546 & 1555 \\
\hline Unique reflections & 1469 & 1463 & 1472 & 1466 & 1470 & 1477 \\
\hline$R_{\text {int }}$ value(\%) & 1.79 & 1.83 & 2.43 & 7.96 & 1.14 & 2.36 \\
\hline Unqiue $\mathrm{F}_{0}>4 \sigma\left(\mathrm{F}_{0}\right)$ & 1447 & 1392 & 1413 & 1229 & 1461 & 1369 \\
\hline $\mathrm{F}(000)$ & 520.8 & 522.8 & 522.0 & 523.5 & 523.2 & 522.0 \\
\hline$R$ value(\%) & 3.38 & 3.46 & 3.77 & 5.04 & 3.17 & 3.31 \\
\hline$R \mathrm{w}$ value(\%) & 13.92 & 14.60 & 20.66 & 19.07 & 11.06 & 10.80 \\
\hline Goodness of fit & 1.296 & 1.204 & 1.247 & 1.257 & 1.295 & 1.216 \\
\hline$\mu\left(\mathrm{mm}^{-1}\right)$ & 6.12 & 6.26 & 6.16 & 6.31 & 6.28 & 6.24 \\
\hline
\end{tabular}

${ }^{\text {a }}$ The high $R$ value for Tri 4 is due to a tiny crystal 
Table 3a Atomic coordinates and anisotropic displacement parameters $\left(\AA^{2}\right)$ for Tri1

\begin{tabular}{lllllllllll}
\hline Atom & $x$ & $y$ & $z$ & $U_{\mathrm{eq}}$ & $U_{11}$ & $U_{22}$ & $U_{33}$ & $U_{12}$ & $U_{13}$ & $U_{23}$ \\
\hline $\mathrm{A} 1$ & $0.2383(2)$ & 0.25 & $0.8479(2)$ & $0.0231(5)$ & $0.026(1)$ & $0.0222(9)$ & $0.023(1)$ & 0 & $0.0120(8)$ & 0 \\
$\mathrm{~A} 2$ & $0.40553(6)$ & 0.25 & $0.57232(6)$ & $0.0202(3)$ & $0.0191(5)$ & $0.0221(5)$ & $0.0180(5)$ & 0 & $0.0065(3)$ & 0 \\
$\mathrm{M} 1$ & 0 & 0 & 0 & $0.0201(6)$ & $0.019(1)$ & $0.020(1)$ & $0.020(1)$ & $0.001(1)$ & $0.006(1)$ & $-0.001(1)$ \\
$\mathrm{M} 2$ & 0 & 0 & 0.5 & $0.0196(6)$ & $0.021(1)$ & $0.018(1)$ & $0.020(1)$ & $0.001(1)$ & $0.008(1)$ & $-0.000(1)$ \\
M3 & $0.2962(3)$ & 0.25 & $0.2124(2)$ & $0.0192(6)$ & $0.017(1)$ & $0.019(1)$ & $0.020(1)$ & 0 & $0.006(1)$ & 0 \\
Si1 & $0.6635(3)$ & 0.25 & $0.9604(3)$ & $0.0192(6)$ & $0.018(1)$ & $0.018(1)$ & $0.020(1)$ & 0 & $0.007(1)$ & 0 \\
Si2 & $0.6841(3)$ & 0.25 & $0.2811(2)$ & $0.0186(6)$ & $0.018(1)$ & $0.019(1)$ & $0.018(1)$ & 0 & $0.007(1)$ & 0 \\
Si3 & $0.8155(3)$ & 0.25 & $0.6792(3)$ & $0.0183(5)$ & $0.018(1)$ & $0.018(1)$ & $0.018(1)$ & 0 & $0.0069(9)$ & 0 \\
O1 & $0.7664(6)$ & $0.0086(9)$ & $0.9661(6)$ & $0.024(1)$ & $0.025(2)$ & $0.021(2)$ & $0.026(2)$ & $0.003(1)$ & $0.011(2)$ & $0.003(1)$ \\
O2 & $0.6909(6)$ & $0.026(1)$ & $0.6381(6)$ & $0.024(1)$ & $0.025(2)$ & $0.023(2)$ & $0.022(2)$ & $-0.006(1)$ & $0.008(1)$ & $-0.003(1)$ \\
O3 & $0.7931(6)$ & $0.0115(9)$ & $0.3422(6)$ & $0.024(1)$ & $0.022(2)$ & $0.021(2)$ & $0.025(2)$ & $0.003(1)$ & $0.007(1)$ & $0.000(1)$ \\
O4 & $0.0512(9)$ & 0.25 & $0.1276(8)$ & $0.022(1)$ & $0.021(3)$ & $0.021(3)$ & $0.020(3)$ & 0 & $0.007(2)$ & 0 \\
O5 & $0.9534(9)$ & 0.25 & $0.8516(8)$ & $0.021(1)$ & $0.025(3)$ & $0.019(2)$ & $0.020(3)$ & 0 & $0.010(2)$ & 0 \\
O6 & $0.938(1)$ & 0.25 & $0.5922(8)$ & $0.022(1)$ & $0.023(2)$ & $0.020(3)$ & $0.022(3)$ & 0 & $0.008(2)$ & 0 \\
O7 & $0.4904(9)$ & 0.25 & $0.8239(8)$ & $0.021(1)$ & $0.020(3)$ & $0.024(3)$ & $0.021(3)$ & 0 & $0.011(2)$ & 0 \\
O8 & $0.535(1)$ & 0.25 & $0.3290(9)$ & $0.029(1)$ & $0.027(3)$ & $0.039(4)$ & $0.023(3)$ & 0 & $0.012(3)$ & 0 \\
O9 & $0.617(1)$ & 0.25 & $0.1040(9)$ & $0.026(1)$ & $0.026(3)$ & $0.023(3)$ & $0.024(3)$ & 0 & $0.008(2)$ & 0 \\
O10 & $0.0796(9)$ & 0.25 & $0.4238(7)$ & $0.024(1)$ & $0.027(3)$ & $0.023(4)$ & $0.019(3)$ & 0 & $0.007(3)$ & 0 \\
& & & & & & & & &
\end{tabular}


Table 3b Atomic coordinates and anisotropic displacement parameters $\left(\AA^{2}\right)$ for Tri 5

\begin{tabular}{llllllllllc}
\hline Atom & $x$ & $y$ & $z$ & $U_{\mathrm{eq}}$ & $U_{11}$ & $U_{22}$ & $U_{33}$ & $U_{12}$ & $U_{13}$ & $U_{23}$ \\
\hline A1 & $0.2380(2)$ & 0.25 & $0.8477(1)$ & $0.0211(4)$ & $0.0245(8)$ & $0.0212(7)$ & $0.0224(8)$ & 0 & $0.0115(6)$ & 0 \\
A2 & $0.40565(5)$ & 0.25 & $0.57220(5)$ & $0.0202(3)$ & $0.0188(4)$ & $0.0221(4)$ & $0.0185(4)$ & 0 & $0.0065(2)$ & 0 \\
M1 & 0 & 0 & 0 & $0.0204(5)$ & $0.018(1)$ & $0.021(1)$ & $0.021(1)$ & $0.0002(8)$ & $0.0074(8)$ & $-0.0002(8)$ \\
M2 & 0 & 0 & 0.5 & $0.0199(5)$ & $0.020(1)$ & $0.019(1)$ & $0.021(1)$ & $0.0006(8)$ & $0.0085(8)$ & $-0.0001(8)$ \\
M3 & $0.2971(2)$ & 0.25 & $0.2124(2)$ & $0.0212(4)$ & $0.0192(8)$ & $0.0212(9)$ & $0.022(1)$ & 0 & $0.0070(7)$ & 0 \\
Si1 & $0.6638(2)$ & 0.25 & $0.9610(2)$ & $0.0200(4)$ & $0.018(1)$ & $0.021(1)$ & $0.019(1)$ & 0 & $0.0062(8)$ & 0 \\
Si2 & $0.6844(2)$ & 0.25 & $0.2808(2)$ & $0.0199(5)$ & $0.0176(9)$ & $0.021(1)$ & $0.022(1)$ & 0 & $0.0082(8)$ & 0 \\
Si3 & $0.8149(2)$ & 0.25 & $0.6788(2)$ & $0.0195(4)$ & $0.0188(9)$ & $0.0194(9)$ & $0.0194(9)$ & 0 & $0.0071(7)$ & 0 \\
O1 & $0.7667(5)$ & $0.0094(8)$ & $0.9670(5)$ & $0.0240(8)$ & $0.019(1)$ & $0.021(1)$ & $0.029(2)$ & $0.002(1)$ & $0.007(1)$ & $0.003(1)$ \\
O2 & $0.6906(5)$ & $0.0263(8)$ & $0.6371(5)$ & $0.0234(7)$ & $0.017(1)$ & $0.025(1)$ & $0.026(1)$ & $-0.004(1)$ & $0.008(1)$ & $-0.002(1)$ \\
O3 & $0.7929(5)$ & $0.0127(7)$ & $0.3409(4)$ & $0.0233(8)$ & $0.019(1)$ & $0.020(1)$ & $0.026(2)$ & $0.002(1)$ & $0.005(1)$ & $-0.001(1)$ \\
O4 & $0.0501(7)$ & 0.25 & $0.1273(7)$ & $0.024(1)$ & $0.022(2)$ & $0.023(2)$ & $0.026(2)$ & 0 & $0.011(2)$ & 0 \\
O5 & $0.9530(7)$ & 0.25 & $0.8502(6)$ & $0.022(1)$ & $0.021(2)$ & $0.024(2)$ & $0.020(2)$ & 0 & $0.008(2)$ & 0 \\
O6 & $0.9369(8)$ & 0.25 & $0.5929(7)$ & $0.022(1)$ & $0.020(2)$ & $0.022(2)$ & $0.024(2)$ & 0 & $0.010(2)$ & 0 \\
O7 & $0.4907(7)$ & 0.25 & $0.8233(6)$ & $0.023(1)$ & $0.025(2)$ & $0.024(2)$ & $0.019(2)$ & 0 & $0.008(2)$ & 0 \\
O8 & $0.5373(8)$ & 0.25 & $0.3308(7)$ & $0.027(1)$ & $0.023(2)$ & $0.036(3)$ & $0.026(3)$ & 0 & $0.014(2)$ & 0 \\
O9 & $0.6178(8)$ & 0.25 & $0.1034(6)$ & $0.026(1)$ & $0.027(2)$ & $0.031(3)$ & $0.020(2)$ & 0 & $0.009(2)$ & 0 \\
O10 & $0.0822(7)$ & 0.25 & $0.4252(6)$ & $0.022(1)$ & $0.023(3)$ & $0.022(3)$ & $0.022(3)$ & 0 & $0.010(2)$ & 0 \\
& & & & & & & & &
\end{tabular}


Table 3c Atomic coordinates and anisotropic displacement parameters $\left(\AA^{2}\right)$ for Tri 6

\begin{tabular}{lllllllllll}
\hline Atom & $x$ & $y$ & $z$ & $U_{\mathrm{eq}}$ & $U_{11}$ & $U_{22}$ & $U_{33}$ & $U_{12}$ & $U_{13}$ & $U_{23}$ \\
\hline A1 & $0.2383(2)$ & 0.25 & $0.8478(2)$ & $0.0221(4)$ & $0.025(1)$ & $0.022(1)$ & $0.023(1)$ & 0 & $0.0127(8)$ & 0 \\
A2 & $0.40575(7)$ & 0.25 & $0.57210(6)$ & $0.0212(2)$ & $0.0200(4)$ & $0.0231(4)$ & $0.0198(4)$ & 0 & $0.0077(2)$ & 0 \\
M1 & 0 & 0 & 0 & $0.0219(6)$ & $0.022(1)$ & $0.020(1)$ & $0.024(1)$ & $-0.000(1)$ & $0.010(1)$ & $-0.001(1)$ \\
M2 & 0 & 0 & 0.5 & $0.0205(6)$ & $0.019(1)$ & $0.020(1)$ & $0.021(1)$ & $-0.001(1)$ & $0.007(1)$ & $-0.001(1)$ \\
M3 & $0.2969(3)$ & 0.25 & $0.2124(2)$ & $0.0222(5)$ & $0.019(1)$ & $0.024(1)$ & $0.022(1)$ & 0 & $0.0073(8)$ & 0 \\
Si1 & $0.6639(3)$ & 0.25 & $0.9614(3)$ & $0.0212(5)$ & $0.020(1)$ & $0.021(1)$ & $0.022(1)$ & 0 & $0.008(1)$ & 0 \\
Si2 & $0.6842(3)$ & 0.25 & $0.2808(3)$ & $0.0210(5)$ & $0.019(1)$ & $0.022(1)$ & $0.022(1)$ & 0 & $0.009(1)$ & 0 \\
Si3 & $0.8146(3)$ & 0.25 & $0.6794(3)$ & $0.0210(5)$ & $0.019(1)$ & $0.023(1)$ & $0.021(1)$ & 0 & $0.0071(9)$ & 0 \\
O1 & $0.7664(6)$ & $0.0085(5)$ & $0.9686(3)$ & $0.026(1)$ & $0.021(2)$ & $0.022(2)$ & $0.031(2)$ & $0.000(1)$ & $0.009(1)$ & $-0.000(2)$ \\
O2 & $0.6903(6)$ & $0.026(1)$ & $0.6369(5)$ & $0.024(1)$ & $0.021(2)$ & $0.026(2)$ & $0.026(2)$ & $-0.004(1)$ & $0.010(1)$ & $-0.003(2)$ \\
O3 & $0.7941(6)$ & $0.0128(9)$ & $0.3425(6)$ & $0.025(1)$ & $0.022(2)$ & $0.023(2)$ & $0.025(2)$ & $-0.000(1)$ & $0.006(1)$ & $0.001(1)$ \\
O4 & $0.0513(9)$ & 0.25 & $0.1262(9)$ & $0.025(1)$ & $0.020(3)$ & $0.022(3)$ & $0.029(3)$ & 0 & $0.007(2)$ & 0 \\
O5 & $0.9527(9)$ & 0.25 & $0.8505(8)$ & $0.024(1)$ & $0.023(3)$ & $0.027(3)$ & $0.024(3)$ & 0 & $0.011(2)$ & 0 \\
O6 & $0.938(1)$ & 0.25 & $0.5926(8)$ & $0.022(1)$ & $0.027(3)$ & $0.021(3)$ & $0.020(3)$ & 0 & $0.012(2)$ & 0 \\
O7 & $0.491(1)$ & 0.25 & $0.8247(8)$ & $0.026(1)$ & $0.028(3)$ & $0.024(3)$ & $0.027(3)$ & 0 & $0.011(3)$ & 0 \\
O8 & $0.5374(9)$ & 0.25 & $0.3305(9)$ & $0.028(1)$ & $0.023(3)$ & $0.036(2)$ & $0.030(3)$ & 0 & $0.015(3)$ & 0 \\
O9 & $0.619(1)$ & 0.25 & $0.1033(9)$ & $0.029(1)$ & $0.029(3)$ & $0.035(4)$ & $0.026(3)$ & 0 & $0.013(2)$ & 0 \\
O10 & $0.0814(9)$ & 0.25 & $0.4249(7)$ & $0.022(1)$ & $0.024(3)$ & $0.018(3)$ & $0.026(3)$ & 0 & $0.010(3)$ & 0 \\
& & & & & & & &
\end{tabular}


Table 4a Selected interatomic distances $(\AA)$ for Tri1

\begin{tabular}{|c|c|c|c|c|c|}
\hline $\mathrm{A} 1-\mathrm{O} 3 \times 2^{\mathrm{am}}$ & $2.350(5)$ & $\mathrm{M} 1-\mathrm{O} 4 \times 2^{\circ}$ & $1.842(5)$ & Si1-O7 & $1.579(8)$ \\
\hline O7 & $2.356(7)$ & $\mathrm{O} 1 \times 2^{\mathrm{aq}}$ & $1.961(5)$ & $\mathrm{O} 1 \times 2^{\mathrm{s}}$ & $1.637(5)$ \\
\hline $\mathrm{O} 1 \times 2^{\mathrm{tr}}$ & $2.399(5)$ & $\mathrm{O} 5 \times 2^{\mathrm{aq}}$ & $1.979(5)$ & $\mathrm{O} 9^{\mathrm{n}}$ & $1.668(9)$ \\
\hline $\mathrm{O} 5^{\mathrm{p}}$ & $2.550(8)$ & mean & 1.927 & mean & 1.630 \\
\hline $\mathrm{O} 6^{\mathrm{p}}$ & $2.835(9)$ & & & & \\
\hline $\mathrm{O} 9 \times 2^{\mathrm{ab}}$ & $3.075(3)$ & $\mathrm{M} 2-\mathrm{O} 3 \times 2^{\mathrm{ap}}$ & $1.865(5)$ & $\mathrm{Si} 2-\mathrm{O} 8$ & $1.592(9)$ \\
\hline \multirow[t]{2}{*}{ mean } & 2.599 & $\mathrm{O} 10 \times 2^{\mathrm{C}}$ & $1.889(4)$ & $\mathrm{O} 3 \times 2^{\mathrm{s}}$ & $1.630(5)$ \\
\hline & & $\mathrm{O} 6 \times 2^{\mathrm{ap}}$ & $1.903(5)$ & O9 & $1.630(8)$ \\
\hline A2-O7 & $2.327(7)$ & mean & 1.886 & mean & 1.621 \\
\hline $\mathrm{O} 2 \times 2^{\mathrm{am}}$ & $2.487(5)$ & & & & \\
\hline $\mathrm{O} 10$ & $2.650(8)$ & M3-O8 & $1.949(9)$ & $\mathrm{Si} 3-\mathrm{O} 2 \times 2^{\mathrm{s}}$ & $1.624(5)$ \\
\hline $\mathrm{O} 2 \times 2^{\mathrm{s}}$ & $2.664(5)$ & O4 & $1.981(8)$ & O5 & $1.658(8)$ \\
\hline $\mathrm{O} 3 \times 2^{\mathrm{am}}$ & $2.711(5)$ & $\mathrm{O} 2 \times 2^{\mathrm{am}}$ & $2.147(6)$ & O6 & $1.659(8)$ \\
\hline $\mathrm{O} 8 \times 2^{\mathrm{ab}}$ & $2.985(2)$ & $\mathrm{O} 1 \times 2^{\mathrm{am}}$ & $2.208(6)$ & mean & 1.641 \\
\hline mean & 2.667 & mean & 2.107 & & \\
\hline
\end{tabular}

Symmetry transformations used to generate equivalent atoms; a) $-\mathrm{x}+1,-\mathrm{y},-\mathrm{z}+1 ; \mathrm{b})-\mathrm{x}+1,-\mathrm{y}+1,-\mathrm{z}+1 ; \mathrm{c})-\mathrm{x},-\mathrm{y}-\mathrm{z}+1$; d) $\mathrm{x}, \mathrm{y}, \mathrm{z}-1$; e) $\mathrm{x}+1, \mathrm{y}, \mathrm{z}$; f) $-\mathrm{x}+1,-\mathrm{y},-\mathrm{z}+2$; g) $-\mathrm{x}+1,-\mathrm{y}+1,-\mathrm{z}+2$; h) $\mathrm{x}, \mathrm{y}, \mathrm{z}+1$; i) $\mathrm{x}+1, \mathrm{y}, \mathrm{z}+1$; j) $-\mathrm{x}, \mathrm{y}-1 / 2,-\mathrm{z}$; k) $-\mathrm{x}$, $\mathrm{y}+1 / 2,-\mathrm{z} ; 1)-\mathrm{x}, \mathrm{y}+1 / 2,-\mathrm{z}+1$; m) $-\mathrm{x}+1, \mathrm{y}+1 / 2,-\mathrm{z}+1$; n) $-\mathrm{x}, \mathrm{y}-1 / 2,-\mathrm{z}+1$; o) $-\mathrm{x},-\mathrm{y},-\mathrm{z}$;p) $\mathrm{x}-1, \mathrm{y}, \mathrm{z}$; q) $\mathrm{x}-1, \mathrm{y}, \mathrm{z}-1$; r) $-\mathrm{x}+1$, $y+1 / 2,-z+2 ; s) x,-y+1 / 2, z$ 
Table $4 \mathbf{b}$ Selected interatomic distances $(\AA)$ for Tri 5

\begin{tabular}{|c|c|c|c|c|c|}
\hline $\mathrm{A} 1-\mathrm{O} 3 \times 2^{\mathrm{am}}$ & $2.345(4)$ & $\mathrm{M} 1-\mathrm{O} 4 \times 2^{0}$ & $1.843(4)$ & Sil-O7 & $1.586(6)$ \\
\hline $\mathrm{O} 7$ & $2.361(6)$ & $\mathrm{O} 1 \times 2^{\mathrm{aq}}$ & $1.960(4)$ & $\mathrm{O} 1 \times 2^{\mathrm{s}}$ & $1.634(4)$ \\
\hline $\mathrm{O} 1 \times 2^{\mathrm{rr}}$ & $2.398(4)$ & $\mathrm{O} 5 \times 2^{\mathrm{aq}}$ & $1.990(4)$ & $O 9^{\mathrm{n}}$ & $1.651(7)$ \\
\hline $\mathrm{O} 5^{\mathrm{p}}$ & $2.546(6)$ & mean & 1.931 & mean & 1.626 \\
\hline $\mathrm{O} 6^{\mathrm{p}}$ & $2.834(7)$ & & & & \\
\hline $\mathrm{O} 9 \times 2^{\mathrm{ab}}$ & $3.075(2)$ & $\mathrm{M} 2-\mathrm{O} 3 \times 2^{\mathrm{ap}}$ & $1.872(4)$ & $\mathrm{Si} 2-\mathrm{O} 8$ & $1.587(6)$ \\
\hline \multirow[t]{2}{*}{ mean } & 2.597 & $\mathrm{O} 10 \times 2^{\mathrm{c}}$ & $1.895(3)$ & $\mathrm{O} 3 \times 2^{\mathrm{s}}$ & $1.623(4)$ \\
\hline & & $\mathrm{O} 6 \times 2^{\text {ap }}$ & $1.913(4)$ & O9 & $1.635(7)$ \\
\hline A2-O7 & $2.323(6)$ & mean & 1.893 & mean & 1.617 \\
\hline $\mathrm{O} 2 \times 2^{\mathrm{am}}$ & $2.482(4)$ & & & & \\
\hline $\mathrm{O} 10$ & $2.629(6)$ & M3-O8 & $1.965(6)$ & $\mathrm{Si} 3-\mathrm{O} 2 \times 2^{\mathrm{s}}$ & $1.622(4)$ \\
\hline $\mathrm{O} 2 \times 2^{\mathrm{s}}$ & $2.662(4)$ & $\mathrm{O} 4$ & $1.997(6)$ & O5 & $1.651(6)$ \\
\hline $\mathrm{O} 3 \times 2^{\mathrm{am}}$ & $2.724(4)$ & $\mathrm{O} 2 \times 2^{\mathrm{am}}$ & $2.158(4)$ & O6 & $1.649(6)$ \\
\hline $\mathrm{O} 8 \times 2^{\mathrm{ab}}$ & $2.983(2)$ & $\mathrm{O} 1 \times 2^{\mathrm{am}}$ & $2.218(4)$ & mean & 1.636 \\
\hline mean & 2.665 & mean & 2.119 & & \\
\hline
\end{tabular}

Symmetry transformations used to generate equivalent atoms; a) $-\mathrm{x}+1,-\mathrm{y},-\mathrm{z}+1 ; \mathrm{b})-\mathrm{x}+1,-\mathrm{y}+1,-\mathrm{z}+1$; c) $-\mathrm{x},-\mathrm{y}-\mathrm{z}+1$; d) $\mathrm{x}, \mathrm{y}, \mathrm{z}-1$; e) $\mathrm{x}+1, \mathrm{y}, \mathrm{z}$; f) $-\mathrm{x}+1,-\mathrm{y},-\mathrm{z}+2$; g) $-\mathrm{x}+1,-\mathrm{y}+1,-\mathrm{z}+2$; h) $\mathrm{x}, \mathrm{y}, \mathrm{z}+1$; i) $\mathrm{x}+1, \mathrm{y}, \mathrm{z}+1$; j) $-\mathrm{x}, \mathrm{y}-1 / 2,-\mathrm{z}$; k) -x, $\mathrm{y}+1 / 2,-\mathrm{z}$; 1) -x, y+1/2, -z+1; m) $-\mathrm{x}+1, \mathrm{y}+1 / 2,-\mathrm{z}+1$; n) $-\mathrm{x}, \mathrm{y}-1 / 2,-\mathrm{z}+1$; o) $-\mathrm{x},-\mathrm{y},-\mathrm{z}$;p) $\mathrm{x}-1, \mathrm{y}, \mathrm{z}$; q) $\mathrm{x}-1, \mathrm{y}, \mathrm{z}-1$; r) $-\mathrm{x}+1$, $\mathrm{y}+1 / 2,-\mathrm{z}+2 ; \mathrm{s}) \mathrm{x},-\mathrm{y}+1 / 2, \mathrm{z}$ 
Table4c Selected interatomic distances ( $\AA$ ) for Tri 6

\begin{tabular}{|c|c|c|c|c|c|}
\hline $\mathrm{A} 1-\mathrm{O} 3 \times 2^{\mathrm{am}}$ & $2.356(5)$ & $\mathrm{M} 1-\mathrm{O} 4 \times 2^{\circ}$ & $1.836(5)$ & Si1-O7 & $1.579(7)$ \\
\hline O7 & $2.357(8)$ & $\mathrm{O} 1 \times 2^{\mathrm{aq}}$ & $1.969(5)$ & $\mathrm{O} 1 \times 2^{\mathrm{s}}$ & $1.635(5)$ \\
\hline $\mathrm{O} 1 \times 2^{\mathrm{tr}}$ & $2.381(6)$ & $\mathrm{O} 5 \times 2^{\mathrm{aq}}$ & $1.988(5)$ & $\mathrm{O} 9^{\mathrm{n}}$ & $1.641(9)$ \\
\hline $\mathrm{O} 5^{\mathrm{p}}$ & $2.554(8)$ & mean & 1.931 & mean & 1.623 \\
\hline $\mathrm{O} 6^{\mathrm{p}}$ & $2.836(8)$ & & & & \\
\hline $\mathrm{O} 9 \times 2^{\mathrm{ab}}$ & 3.073(3) & $\mathrm{M} 2-\mathrm{O} 3 \times 2^{\mathrm{ap}}$ & $1.859(5)$ & $\mathrm{Si2}-\mathrm{O} 8$ & $1.583(8)$ \\
\hline \multirow[t]{2}{*}{ mean } & 2.596 & $\mathrm{O} 10 \times 2^{\mathrm{c}}$ & $1.893(4)$ & $\mathrm{O} 3 \times 2^{\mathrm{s}}$ & $1.631(5)$ \\
\hline & & $\mathrm{O} 6 \times 2^{\mathrm{ap}}$ & $1.909(4)$ & O9 & $1.637(9)$ \\
\hline $\mathrm{A} 2-\mathrm{O} 7$ & $2.337(8)$ & mean & 1.887 & mean & 1.621 \\
\hline $\mathrm{O} 2 \times 2^{\mathrm{am}}$ & $2.480(5)$ & & & & \\
\hline $\mathrm{O} 10$ & $2.638(7)$ & M3-O8 & $1.967(8)$ & $\mathrm{Si} 3-\mathrm{O} 2 \times 2^{\mathrm{s}}$ & $1.622(5)$ \\
\hline $\mathrm{O} 2 \times 2^{\mathrm{s}}$ & $2.660(5)$ & $\mathrm{O} 4$ & $1.986(8)$ & O5 & $1.650(8)$ \\
\hline $\mathrm{O} 3 \times 2^{\mathrm{am}}$ & $2.725(5)$ & $\mathrm{O} 2 \times 2^{\mathrm{am}}$ & $2.159(6)$ & O6 & $1.663(8)$ \\
\hline $\mathrm{O} 8 \times 2^{\mathrm{ab}}$ & $2.985(2)$ & $\mathrm{O} 1 \times 2^{\mathrm{am}}$ & $2.227(5)$ & mean & 1.639 \\
\hline mean & 2.668 & mean & 2.121 & & \\
\hline
\end{tabular}

Symmetry transformations used to generate equivalent atoms; a) $-\mathrm{x}+1,-\mathrm{y},-\mathrm{z}+1$; b) $-\mathrm{x}+1,-\mathrm{y}+1,-\mathrm{z}+1$; c) $-\mathrm{x},-\mathrm{y}-\mathrm{z}+1$; d) $\mathrm{x}, \mathrm{y}, \mathrm{z}-1$; e) $\mathrm{x}+1, \mathrm{y}, \mathrm{z}$; f) $-\mathrm{x}+1,-\mathrm{y},-\mathrm{z}+2$; g) $-\mathrm{x}+1,-\mathrm{y}+1,-\mathrm{z}+2$; h) $\mathrm{x}, \mathrm{y}, \mathrm{z}+1$; i) $\mathrm{x}+1, \mathrm{y}, \mathrm{z}+1$; j) $-\mathrm{x}, \mathrm{y}-1 / 2,-\mathrm{z}$; k) -x, $\mathrm{y}+1 / 2,-\mathrm{z}$; 1) -x, y+1/2, -z+1; m) -x+1, y+1/2, -z+1; n) -x, y-1/2, -z+1; o) -x, -y, -z ;p) x-1, y, z; q) $\mathrm{x}-1, \mathrm{y}, \mathrm{z}-1$; r) $-\mathrm{x}+1$, $\mathrm{y}+1 / 2,-\mathrm{z}+2 ; \mathrm{s}) \mathrm{x},-\mathrm{y}+1 / 2, \mathrm{z}$ 
Table 5a Bond-valence calculation for Tri 1

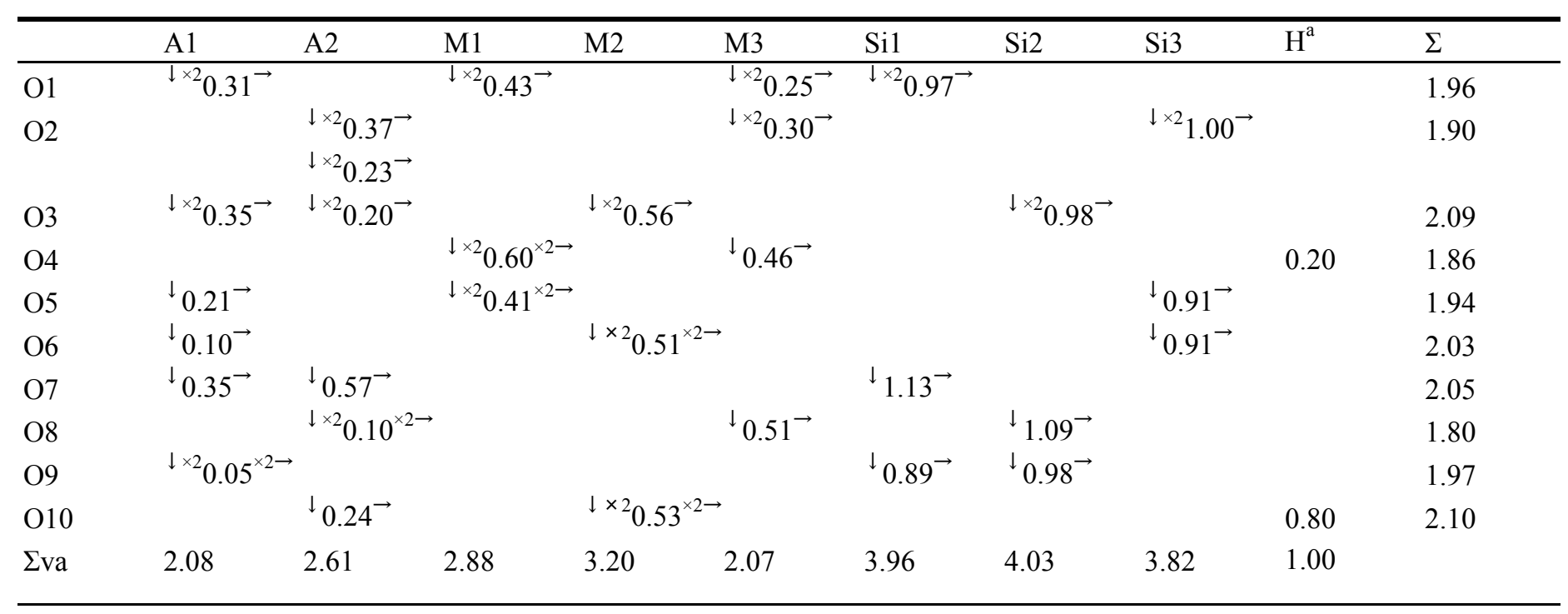

The bond-valence parameters are from Brese and O'Keeffe (1991)

${ }^{\mathrm{a}}$ The bond valence distribution of $\mathrm{H}$ atom for $\mathrm{O} 4$ and $\mathrm{O} 10$ atoms was assigned as that in the the most common coordination (Brown 1976; Hawthorne 1992) 
Table 5b Bond-valence calculation for Tri 5

\begin{tabular}{|c|c|c|c|c|c|c|c|c|c|c|}
\hline & A1 & A2 & M1 & M2 & M3 & Si1 & $\mathrm{Si} 2$ & $\mathrm{Si} 3$ & $\mathrm{H}^{\mathrm{a}}$ & $\Sigma$ \\
\hline O1 & $\downarrow^{\times 2} 0.30^{\rightarrow}$ & & $\downarrow \times 20.43 \rightarrow$ & & $\downarrow \sqrt{\times 2} 0.24 \rightarrow$ & $\downarrow \times 20.97^{\rightarrow}$ & & & & 1.94 \\
\hline \multirow{2}{*}{$\mathrm{O} 2$} & & $\downarrow \times 20.38^{\rightarrow}$ & & & $\downarrow \times 20.28^{\rightarrow}$ & & & $\downarrow \times 21.01^{\rightarrow}$ & & 1.91 \\
\hline & & $\stackrel{\downarrow}{ }{ }^{\perp} 0.24^{\rightarrow}$ & & & & & & & & \\
\hline $\mathrm{O} 3$ & $\downarrow \times 20.35^{\rightarrow}$ & $\downarrow \times 20.20 \rightarrow$ & & ${ }^{\downarrow \times 2} 0.55^{\rightarrow}$ & & & $\downarrow \times 21.00 \rightarrow$ & & & 2.10 \\
\hline $\mathrm{O} 4$ & & & $\downarrow \times 20.60^{\times 2 \rightarrow}$ & & ${ }^{\downarrow} 0.44 \rightarrow$ & & & & 0.2 & 1.84 \\
\hline O5 & ${ }^{\downarrow} 0.20 \rightarrow$ & & $\downarrow \times 20.40^{\times 2 \rightarrow}$ & & & & & ${ }^{\downarrow} 0.93 \overrightarrow{ }$ & & 1.93 \\
\hline O6 & ${ }^{\downarrow} 0.09^{\rightarrow}$ & & & $\downarrow \times 20.49^{\times 2 \rightarrow}$ & & & & ${ }^{\downarrow} 0.94 \rightarrow$ & & 2.01 \\
\hline $\mathrm{O} 7$ & ${ }^{\downarrow} 0.33 \rightarrow$ & ${ }^{\downarrow} 0.59^{\rightarrow}$ & & & & ${ }^{\downarrow} 1.11^{\rightarrow}$ & & & & 2.03 \\
\hline O8 & & $\downarrow \times 20.10^{\times 2 \rightarrow}$ & & & ${ }^{\downarrow} 0.48^{\rightarrow}$ & & ${ }^{\downarrow} 1.10^{\rightarrow}$ & & & 1.78 \\
\hline O9 & $\downarrow \times 20.05^{\times 2 \rightarrow}$ & & & & & ${ }^{\downarrow} 0.93^{\rightarrow}$ & ${ }^{\downarrow} 0.97^{\rightarrow}$ & & & 2.00 \\
\hline $\mathrm{O} 10$ & & ${ }^{\downarrow} 0.26 \overrightarrow{ }$ & & $\downarrow \times 20.52^{\times 2 \rightarrow}$ & & & & & 0.8 & 2.10 \\
\hline$\Sigma \mathrm{va}$ & 2.02 & 2.69 & 2.86 & 3.12 & 1.96 & 3.98 & 4.07 & 3.89 & 1.00 & \\
\hline
\end{tabular}

The bond-valence parameters are from Brese and O'Keeffe (1991)

${ }^{\text {a }}$ The bond valence distribution of $\mathrm{H}$ atom for $\mathrm{O} 4$ and $\mathrm{O} 10$ atoms was assigned as that in the the most common coordination (Brown 1976; Hawthorne 1992) 
Table 5c Bond-valence calculation for Tri 6

\begin{tabular}{|c|c|c|c|c|c|c|c|c|c|c|}
\hline & $\mathrm{A} 1$ & A2 & M1 & M2 & M3 & Si1 & $\mathrm{Si} 2$ & $\mathrm{Si} 3$ & $\mathrm{H}^{\mathrm{a}}$ & $\Sigma$ \\
\hline O1 & $\downarrow \times 20.31^{\rightarrow}$ & & $\downarrow \times 20.42 \rightarrow$ & & $\downarrow \sqrt{\times 2} 0.24 \rightarrow$ & $\downarrow \times 20.97^{\rightarrow}$ & & & & 1.94 \\
\hline \multirow[t]{2}{*}{$\mathrm{O} 2$} & & $\downarrow \times 20.38 \rightarrow$ & & & $\downarrow \times 20.29^{\rightarrow}$ & & & $\downarrow \times 21.01^{\rightarrow}$ & & 1.92 \\
\hline & & $\stackrel{\downarrow}{ }{ }^{\perp} 0.24^{\rightarrow}$ & & & & & & & & \\
\hline $\mathrm{O} 3$ & $\downarrow \times 20.33 \rightarrow$ & $\downarrow \times 20.20 \rightarrow$ & & ${ }^{\downarrow \times 2} 0.57^{\rightarrow}$ & & & $\stackrel{\downarrow \times 2}{ } 0.98^{\rightarrow}$ & & & 2.08 \\
\hline $\mathrm{O} 4$ & & & ${ }^{\downarrow \times 2} 0.61^{\times 2 \rightarrow}$ & & ${ }^{\downarrow} 0.46 \rightarrow$ & & & & 0.2 & 1.88 \\
\hline $\mathrm{O} 5$ & ${ }^{\downarrow} 0.20 \rightarrow$ & & $\downarrow \times 20.40^{\times 2 \rightarrow}$ & & & & & ${ }^{\downarrow} 0.93 \overrightarrow{ }$ & & 1.93 \\
\hline O6 & ${ }^{\downarrow} 0.09^{\rightarrow}$ & & & $\downarrow \times 20.50^{\times 2 \rightarrow}$ & & & & ${ }^{\downarrow} 0.90 \rightarrow$ & & 1.99 \\
\hline $\mathrm{O} 7$ & ${ }^{\downarrow} 0.33 \rightarrow$ & ${ }^{\downarrow} 0.56 \overrightarrow{ }$ & & & & ${ }^{\downarrow} 1.13 \rightarrow$ & & & & 2.02 \\
\hline O8 & & $\downarrow \times 20.10^{\times 2 \rightarrow}$ & & & ${ }^{\downarrow} 0.49^{\rightarrow}$ & & ${ }^{\downarrow} 1.12 \rightarrow$ & & & 1.81 \\
\hline O9 & $\downarrow \times 20.05^{\times 2 \rightarrow}$ & & & & & ${ }^{\downarrow} 0.96 \rightarrow$ & ${ }^{\downarrow} 0.97^{\rightarrow}$ & & & 2.03 \\
\hline $\mathrm{O} 10$ & & ${ }^{\downarrow} 0.25^{\rightarrow}$ & & $\downarrow \times 20.52^{\times 2 \rightarrow}$ & & & & & 0.8 & 2.09 \\
\hline$\Sigma \mathrm{va}$ & 2.00 & 2.65 & 2.86 & 3.18 & 2.01 & 4.03 & 4.05 & 3.85 & 1.00 & \\
\hline
\end{tabular}

The bond-valence parameters are from Brese and O'Keeffe (1991)

${ }^{a}$ The bond valence distribution of $\mathrm{H}$ atom for $\mathrm{O} 4$ and $\mathrm{O} 10$ atoms was assigned as that in the the most common coordination (Brown 1976; Hawthorne 1992) 
Table 6 Aassinged and refined site occupancies of dissakisites from Trimouns and occupants assinged on a basis of representative EPMA values of those from Balchen Mountain

\begin{tabular}{|c|c|c|c|}
\hline Sample (1) & Assigned and refined occupants through crystal structure refinement ${ }^{a}$ & & \\
\hline & A1 site (refined) & & M1 site (assinged) \\
\hline Tri 1 & $\mathrm{Ca}_{0.998} \square_{0.002}{ }^{\mathrm{d}}$ & Tri 1 & $\mathrm{Al}_{1.000}$ \\
\hline Tri 2 & $\mathrm{Ca}_{0.988} \square_{0.012}{ }^{\mathrm{d}}$ & Tri 2 & $\mathrm{Al}_{1.000}$ \\
\hline Tri 3 & $\mathrm{Ca}_{0.990} \square_{0.010}{ }^{\mathrm{d}}$ & Tri 3 & $\mathrm{Al}_{1.000}$ \\
\hline Tri 4 & $\mathrm{Ca}_{1.000}$ & Tri 4 & $\mathrm{Al}_{1.000}$ \\
\hline Tri 5 & $\mathrm{Ca}_{0.961} \square_{0.039}{ }^{\mathrm{d}}$ & Tri 5 & $\mathrm{Al}_{1.000}$ \\
\hline Tri 6 & $\mathrm{Ca}_{0.952} \square_{0.048}{ }^{\mathrm{d}}$ & Tri 6 & $\mathrm{Al}_{1.000}$ \\
\hline & A2 site (refined) & & M3 site (refined) \\
\hline Tri 1 & $\mathrm{La}_{0.202} \mathrm{Ce}_{0.349} \mathrm{Pr}_{0.059} \mathrm{Nd}_{0.197} \mathrm{Sm}_{0.035} \mathrm{Gd}_{0.018} \mathrm{Ca}_{0.115} \mathrm{Fe}^{2+}{ }_{0.025}$ & Tri 1 & $\mathrm{Al}_{0.126} \mathrm{Fe}^{2+}{ }_{0.213} \mathrm{Mg}_{0.661}$ \\
\hline Tri 2 & $\mathrm{La}_{0.215} \mathrm{Ce}_{0.361} \mathrm{Pr}_{0.059} \mathrm{Nd}_{0.195} \mathrm{Sm}_{0.033} \mathrm{Gd}_{0.018} \mathrm{Ca}_{0.119}$ & Tri 2 & $\mathrm{Al}_{0.089} \mathrm{Fe}^{2+}{ }_{0.258} \mathrm{Mg}_{0.651} \square_{0.002}{ }^{\mathrm{d}}$ \\
\hline Tri 3 & $\mathrm{La}_{0.219} \mathrm{Ce}_{0.357} \mathrm{Pr}_{0.055} \mathrm{Nd}_{0.186} \mathrm{Sm}_{0.032} \mathrm{Gd}_{0.015} \mathrm{Ca}_{0.111} \mathrm{Fe}^{2+}{ }_{0.025}$ & Tri 3 & $\mathrm{Al}_{0.102} \mathrm{Fe}^{2+}{ }_{0.249} \mathrm{Mg}_{0.649}$ \\
\hline Tri 4 & $\mathrm{La}_{0.196} \mathrm{Ce}_{0.361} \mathrm{Pr}_{0.057} \mathrm{Nd}_{0.215} \mathrm{Sm}_{0.038} \mathrm{Gd}_{0.021} \mathrm{Ca}_{0.112}$ & Tri 4 & $\mathrm{Al}_{0.122} \mathrm{Fe}^{2+}{ }_{0.256} \mathrm{Mg}_{0.598} \square_{0.024}{ }^{\mathrm{d}}$ \\
\hline Tri 5 & $\mathrm{La}_{0.220} \mathrm{Ce}_{0.379} \mathrm{Pr}_{0.054} \mathrm{Nd}_{0.178} \mathrm{Sm}_{0.027} \mathrm{Gd}_{0.014} \mathrm{Ca}_{0.128}$ & Tri 5 & $\mathrm{Al}_{0.103} \mathrm{Fe}^{2+}{ }_{0.335} \mathrm{Mg}_{0.526} \square_{0.036}{ }^{\mathrm{d}}$ \\
\hline Tri 6 & $\mathrm{La}_{0.220} \mathrm{Ce}_{0.364} \mathrm{Pr}_{0.062} \mathrm{Nd}_{0.184} \mathrm{Sm}_{0.027} \mathrm{Gd}_{0.016} \mathrm{Ca}_{0.101} \mathrm{Fe}^{2+}{ }_{0.026}$ & Tri 6 & $\mathrm{Al}_{0.100} \mathrm{Fe}^{2+}{ }_{0.318} \mathrm{Mg}_{0.582}$ \\
\hline Sample (2) & Site occupants assinged at representative EPMA values ${ }^{b}$ & & \\
\hline & A1 site (assinged) & & M1 site (assinged) \\
\hline Bal 1 & $\mathrm{Ca}_{0.969} \square_{0.03}{ }^{\mathrm{d}}$ & Bal 1 & $\mathrm{Al}_{0.85} \mathrm{Ti}_{0.08} \mathrm{Fe}^{2+}{ }_{0.07}$ \\
\hline Bal 2 & $\mathrm{Ca}_{0.955} \square_{0.045}{ }^{\mathrm{d}}$ & Bal 2 & $\mathrm{Al}_{0.83} \mathrm{Ti}_{0.079} \mathrm{Fe}^{2+}{ }_{0.091}$ \\
\hline Bal 3 & $\mathrm{Ca}_{0.965} \square_{0.035}{ }^{\mathrm{d}}$ & Bal 3 & $\mathrm{Al}_{0.84} \mathrm{Ti}_{0.08} \mathrm{Fe}^{2+}{ }_{0.08}$ \\
\hline Bal 4 & $\mathrm{Ca}_{0.917} \square_{0.083}{ }^{\mathrm{d}}$ & Bal 4 & $\mathrm{Al}_{0.73} \mathrm{Ti}_{0.08} \mathrm{Fe}^{2+} 0.19$ \\
\hline Bal 5 & $\mathrm{Ca}_{0.922} \square_{0.078}{ }^{\mathrm{d}}$ & Bal 5 & $\mathrm{Al}_{0.71} \mathrm{Ti}_{0.09} \mathrm{Fe}^{2+}{ }_{0.20}$ \\
\hline & A2 site (assinged) & & M3 site (assinged) \\
\hline Bal 1 & $\mathrm{La}_{0.325} \mathrm{Ce}_{0.327} \mathrm{Pr}_{0.032} \mathrm{Nd}_{0.068} \mathrm{Sm}_{0.010} \mathrm{Gd}_{0.034} \mathrm{Ca}_{0.124} \mathrm{Fe}^{2+}{ }_{0.08}$ & Bal 1 & $\mathrm{Fe}^{2+}{ }_{0.04} \mathrm{Mg}_{0.96}$ \\
\hline Bal 2 & $\mathrm{La}_{0.324} \mathrm{Ce}_{0.32} \mathrm{Pr}_{0.033} \mathrm{Nd}_{0.070} \mathrm{Sm}_{0.011} \mathrm{Gd}_{0.035} \mathrm{Ca}_{0.143} \mathrm{Fe}^{2+}{ }_{0.064}$ & Bal 2 & $\mathrm{Fe}^{2+}{ }_{0.032} \mathrm{Mg}_{0.968}$ \\
\hline Bal 3 & $\mathrm{La}_{0.33} \mathrm{Ce}_{0.33} \mathrm{Pr}_{0.034} \mathrm{Nd}_{0.069} \mathrm{Sm}_{0.010} \mathrm{Gd}_{0.034} \mathrm{Ca}_{0.131} \mathrm{Fe}^{2+}{ }_{0.062}$ & Bal 3 & $\mathrm{Fe}^{2+}{ }_{0.050} \mathrm{Mg}_{0.95}$ \\
\hline Bal 4 & $\mathrm{La}_{0.32} \mathrm{Ce}_{0.36} \mathrm{Pr}_{0.039} \mathrm{Nd}_{0.085} \mathrm{Sm}_{0.011} \mathrm{Gd}_{0.039} \mathrm{Ca}_{0.098} \mathrm{Fe}^{2+}{ }_{0.048}$ & Bal 4 & $\mathrm{Mg}_{1.04}{ }^{\mathrm{c}}$ \\
\hline Bal 5 & $\mathrm{La}_{0.323} \mathrm{Ce}_{0.358} \mathrm{Pr}_{0.037} \mathrm{Nd}_{0.083} \mathrm{Sm}_{0.011} \mathrm{Gd}_{0.038} \mathrm{Ca}_{0.112} \mathrm{Fe}^{2+}{ }_{0.038}$ & Bal 5 & $\mathrm{Mg}_{1.06}{ }^{\mathrm{c}}$ \\
\hline
\end{tabular}

For Tri 1-6 and Bal 1-5, their site contents are $\mathrm{Al}_{1.000}$ for $\mathrm{M} 2, \mathrm{Si}_{1.000}$ for $\mathrm{Si} 1, \mathrm{Si}_{1.000}$ for $\mathrm{Si} 2$, and $\mathrm{Si}_{1.000}$ for $\mathrm{Si} 3$

${ }^{a}$ The other site occupancies for the present dissakisites from Trimoun (Tri 1-5) were refined by the sturucture analysis

${ }^{\mathrm{b}}$ The present chemical-zoned dissakisites from Balchen Mountain (Bal 1-5) was too small to perform the structure analysis for a

single crystal. Therefore, the site occupancies for dissakisite from Balchen Mountain (Bal 1-5) were fixed at the representative EMPA values (Table 1)

${ }^{\mathrm{c}}$ Although the Mg occupancies (M3 site) in Bal 4,5 exceed 1.000, the excess Mg fall within the standard deviation of Mg

${ }^{\mathrm{d}}$ The defects of $\mathrm{A} 1$ and $\mathrm{M} 3$ sites in the present dissakisites fall within the standard deviation of the elements $\left(\mathrm{Ca}^{2+}, \mathrm{Al}^{3+}, \mathrm{Fe}^{2+}\right.$ and $\mathrm{Mg}^{2+}$ ) occupying $\mathrm{A} 1$ and $\mathrm{M} 3$ sites 
Table 7 Volumes $\left(\AA^{3}\right)$ of coordination polyhedra for dissakisites

\begin{tabular}{lcccc}
\hline & zone & $\mathrm{A} 2\left(\AA^{3}\right)$ & $\mathrm{M} 3\left(\AA^{3}\right)$ & $\mathrm{A} 2+\mathrm{M} 3\left(\AA^{3}\right)$ \\
\hline Tri 1 (this study) & dark & 37.73 & 11.85 & 49.58 \\
Tri 2 (this study) & dark & 37.43 & 11.63 & 49.06 \\
Tri 3 (this study) & dark & 37.47 & 11.87 & 49.34 \\
Tri 4 (this study) & bright & 37.49 & 12.15 & 49.64 \\
Tri 5 (this study) & bright & 37.64 & 12.04 & 49.68 \\
Tri 6 (this study) & homogeneous & 37.76 & 12.07 & 49.83 \\
Balchen Mountain & - & 38.12 & 11.93 & 50.05 \\
(Rouse and Peacor, 1993) $_{\text {The Ulten zone }}^{\text {a }}$ & & & & \\
(Lavina et al., 2006) $^{\text {anina }}$ & - & 39.01 & 11.95 & 50.96 \\
\hline
\end{tabular}

Tri1-Tri6 represent six zones in Figs. 1a and 1b

${ }^{a}$ Data for untreated DISS3 in Lavina et al. (2006) 

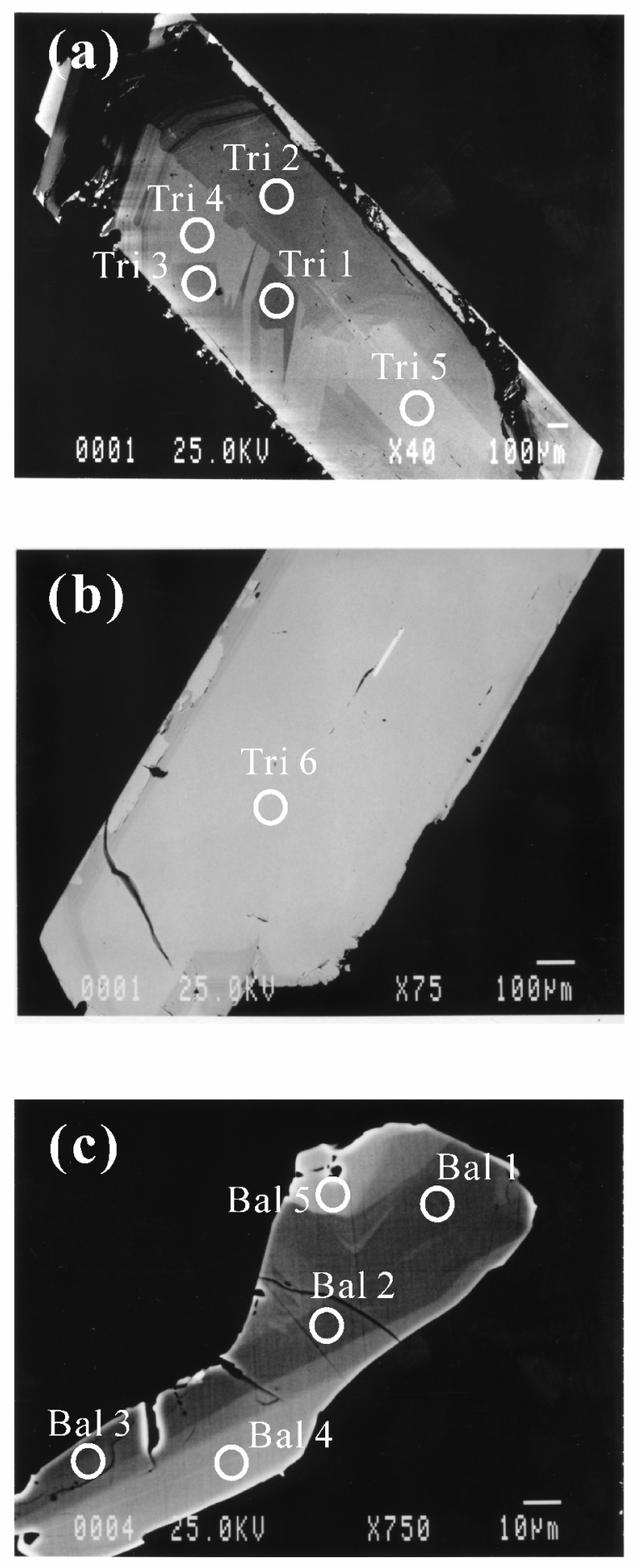

Fig. 1 Back-scattered electron images of dissakisite: (a) chemical zoning of dark brown dissakisite from Trimouns, (b) chemical homogeneity of light brown and transparent dissakisite from Trimouns, (c) chemical zoning of light brown dissakisite from Balchen Mountain. The crystals (a) and (c) show complex internal zoning, as documented in different shades of gray, with straight boundary segments. The homogeneous core lies in the crystal of dissakisite from Trimouns (Fig. 1b), but the thin-rim fringed by chemical zoning was observed. 

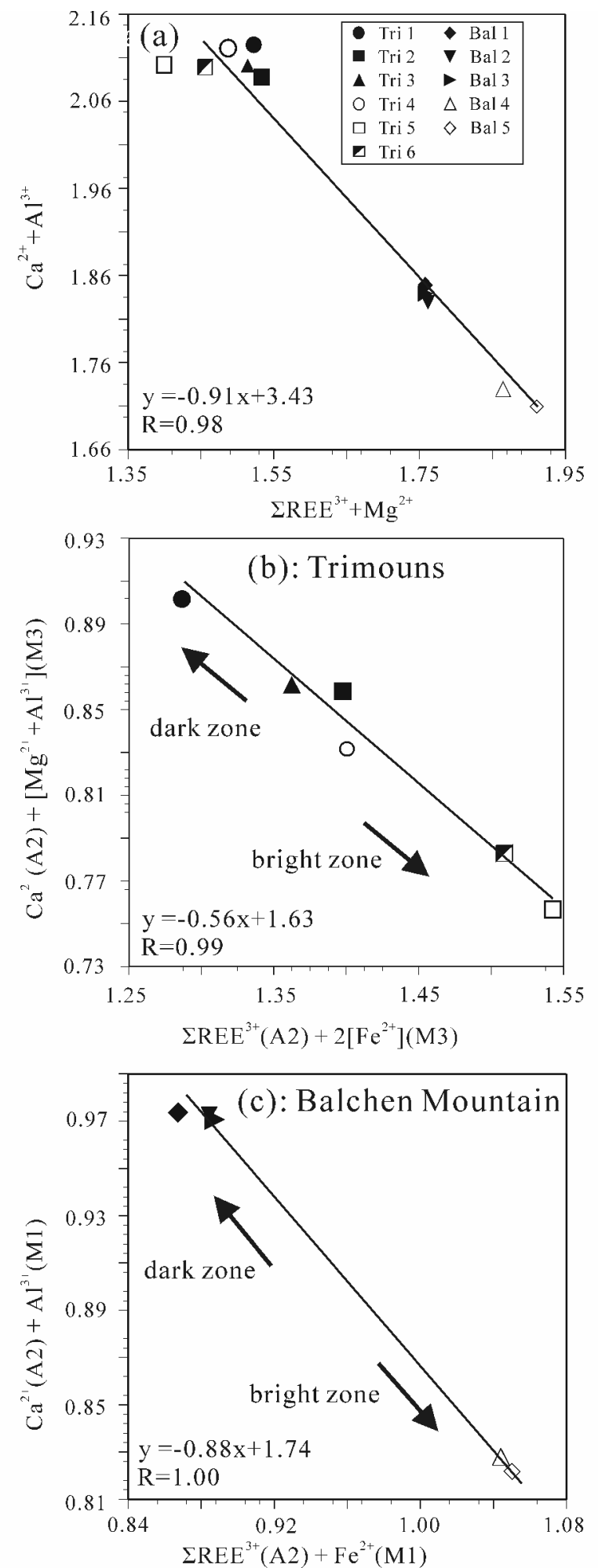

Fig. 2. Diagrams illustrating the potential combinations of elements for several zones of dissakisites from Trimouns and Balchen Mountain. The present dissakisites are related to epidote via the coupled substitution. (a) $\mathrm{Ca}^{2+}+\mathrm{Fe}^{3-} \leftrightarrow \mathrm{REE}^{i+}+\mathrm{Mg}^{2+}$, reported by Gieré and Sorensen (2004). The coupled substitutions of elements of dissakisite from Trimouns and Balchen Mountain plotted are (b) $\mathrm{Ca}^{3+}(\mathrm{A} 2)+\left(\mathrm{Mg}^{2+}+\mathrm{Al}^{3+}\right)(\mathrm{M} 3) \leftrightarrow \mathrm{REE}^{3+}(\mathrm{A} 2)+2 \mathrm{Fe} \mathrm{e}^{3-}(\mathrm{M} 3)$ (refined by the structure analysis) and (c) $\mathrm{Ca}^{2}$ (A2) $+\mathrm{Al}^{31}$ (M1) $\rightarrow \mathrm{REE}^{31}$ (A2) $+\mathrm{F} 2$ (M1) (assigned on a basis of the representative EMPA values). Units are atoms per formula unit (a.p.f.u.). 
Figure 3
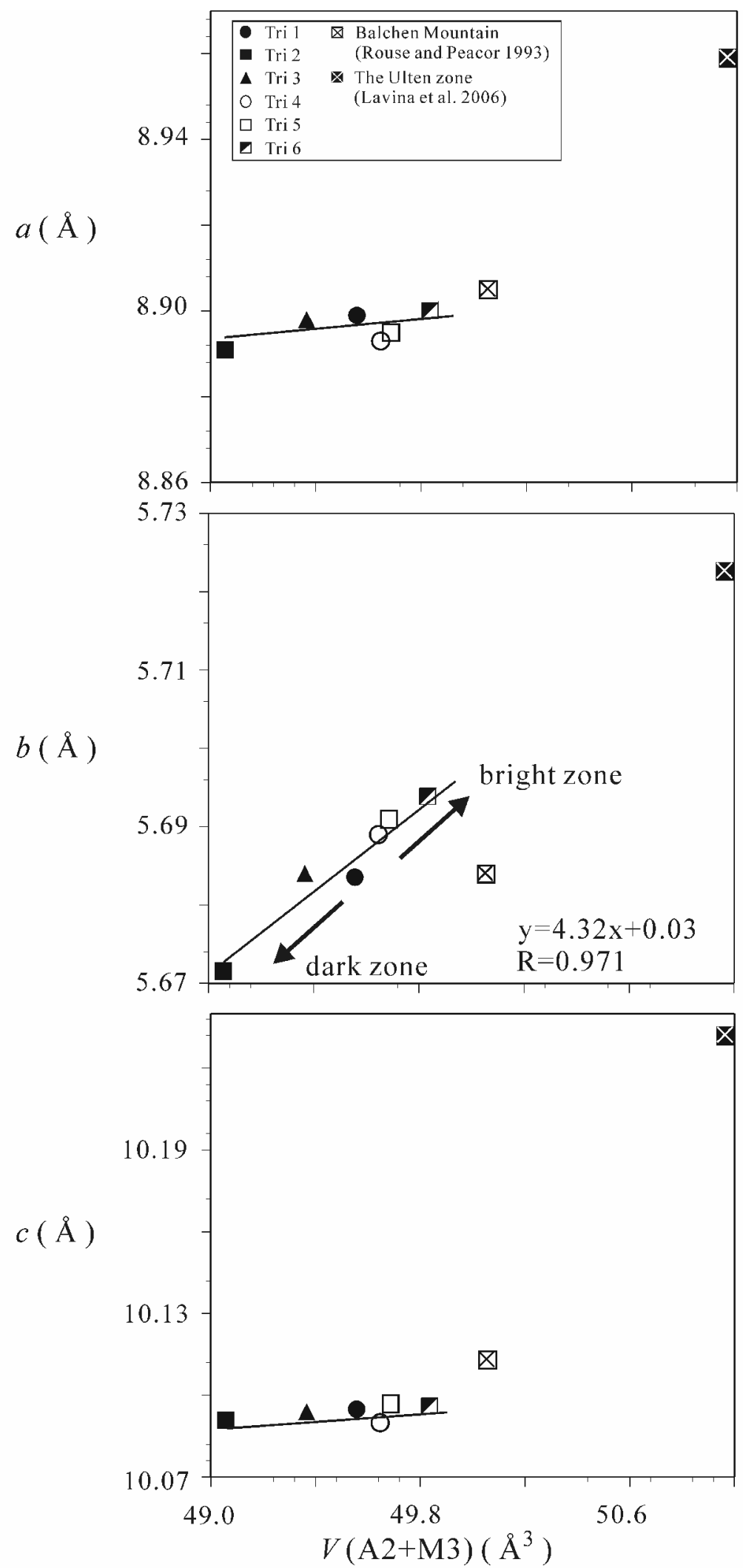

Fig. 3. Lattice parameters vs. the sum of the volumes of A2 and M3 sites. Volumes of the polyhedra are calculated by IVTON program (Balič-Žunič and Vickovic 1996). 


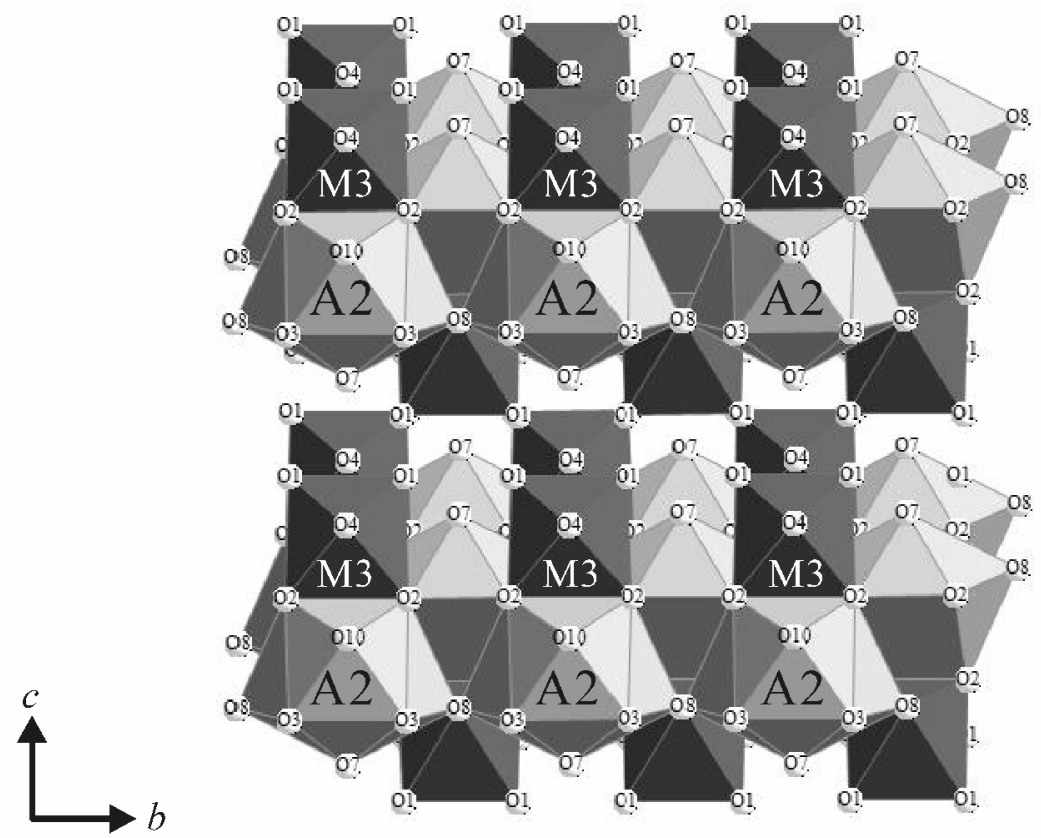

Fig. 4. Projection of crystal structure of dissakisite. Each ten-coordinated A2 polyhedron shares one edge with M3 octahedra. Moreover, the A2 polyhedra form linear single chains with one bridging oxygen atoms per polyhedron, resulting in lengthening the $b$ axis. 